\title{
Effect of soluble amyloid precursor protein-alpha on adult hippocampal neurogenesis in a mouse model of Alzheimer's disease
}

\author{
Shane M. Ohline ${ }^{1,2+}$, Connie Chan ${ }^{1 \dagger}$, Lucia Schoderboeck ${ }^{3}$, Hollie E. Wicky ${ }^{3}$, Warren P. Tate ${ }^{3}$,
} Stephanie M. Hughes ${ }^{3+}$ and Wickliffe C. Abraham ${ }^{1 *+}$ (D)

\begin{abstract}
Soluble amyloid precursor protein-alpha (SAPPa) is a regulator of neuronal and memory mechanisms, while also having neurogenic and neuroprotective effects in the brain. As adult hippocampal neurogenesis is impaired in Alzheimer's disease, we tested the hypothesis that sAPPa delivery would rescue adult hippocampal neurogenesis in an APP/ PS1 mouse model of Alzheimer's disease. An adeno-associated virus-9 (AAV9) encoding murine sAPPa was injected into the hippocampus of 8-month-old wild-type and APP/PS1 mice, and later two different thymidine analogues $(\mathrm{XdU})$ were systemically injected to label adult-born cells at different time points after viral transduction. The proliferation of adult-born cells, cell survival after eight weeks, and cell differentiation into either neurons or astrocytes was studied. Proliferation was impaired in APP/PS1 mice but was restored to wild-type levels by viral expression of sAPPa. In contrast, sAPPa overexpression failed to rescue the survival of XdU+-labelled cells that was impaired in APP/PS1 mice, although it did cause a significant increase in the area density of astrocytes in the granule cell layer across both genotypes. Finally, viral expression of sAPPa reduced amyloid-beta plaque load in APP/PS1 mice in the dentate gyrus and somatosensory cortex. These data add further evidence that increased levels of sAPPa could be therapeutic for the cognitive decline in $A D$, in part through restoration of the proliferation of neural progenitor cells in adults.
\end{abstract}

Keywords: Alzheimer's disease, Adult neurogenesis, sAPPa, Dentate gyrus, APP/PS1, Astrocytes, Proliferation, Differentiation

\section{Introduction}

Alzheimer's disease (AD) is an aging-related neurodegenerative disorder that is the most common form of dementia. It is characterised by a build-up of toxic soluble oligomers of the amyloid- $\beta$ (A $\beta$ ) peptide (both intra- and extracellularly), aggregation of the $A \beta$ into

\footnotetext{
*Correspondence: cliff.abraham@otago.ac.nz

tShane M. Ohline and Connie Chan are equal first authors

† Stephanie M. Hughes and Wickliffe C. Abraham are equal last authors

${ }^{1}$ Department of Psychology, Brain Health Research Centre, Brain Research

New Zealand, University of Otago, Dunedin, New Zealand

Full list of author information is available at the end of the article
}

extracellular insoluble plaques, hyper-phosphorylation of tau proteins with associated generation of toxic neurofibrillary tangles, and impaired cerebrovasculature [1]. These changes trigger neuroinflammation, synapse loss, impaired neurogenesis and ultimately cell death. Despite the intense international research efforts addressing AD, the development of effective therapies has been painfully slow. Accordingly, new therapeutic approaches, based on an increased understanding of the disease mechanism as well as the mechanisms of action of possible therapeutic molecules, are urgently required. A commonly held view regarding the primary or at least major pathophysiology original author(s) and the source, provide a link to the Creative Commons licence, and indicate if changes were made. The images or other third party material in this article are included in the article's Creative Commons licence, unless indicated otherwise in a credit line to the material. If material is not included in the article's Creative Commons licence and your intended use is not permitted by statutory regulation or exceeds the permitted use, you will need to obtain permission directly from the copyright holder. To view a copy of this licence, visit http://creativecommons.org/licenses/by/4.0/. The Creative Commons Public Domain Dedication waiver (http://creativeco mmons.org/publicdomain/zero/1.0/) applies to the data made available in this article, unless otherwise stated in a credit line to the data. 
in $\mathrm{AD}$ centres on the amyloid cascade hypothesis [2]. This states that the over-accumulation of $A \beta$, either by enhanced cleavage of the parent protein amyloid precursor protein (APP), or by decreased clearance, is a critical step in developing AD. More recently, the "beta amyloid dysfunction hypothesis' has been proposed whereby it is the formation of misfolded $A \beta$ soluble synaptotoxic aggregates that is responsible for the pathology, and their formation also leads to a depletion of the functionally important $A \beta$ monomer [3].

Full-length amyloid precursor protein (APP) is a ubiquitously expressed protein that has been localised to synaptic membranes, including both the postsynaptic density and adhesion patches, suggesting that neuronal APP plays a role in both signal transduction and cell adhesion [4]. Proteolytic processing of APP in vivo yields protein fragments which themselves regulate neuronal function [5]. The $\gamma / \beta$ secretases release the $A \beta$ fragment and the $\mathrm{N}$-terminal fragment sAPP $\beta$, whereas $\alpha$-secretase cleavage within the $A \beta$ peptide sequence prevents its production and releases the larger $\mathrm{N}$-terminal fragment soluble amyloid precursor protein-alpha (sAPP $\alpha)$. sAPP $\alpha$ differs from sAPP $\beta$ by only a 16 amino acid extension at its C-terminus, but is generally 100 -fold more potent in regulating neuronal function [6].

Exogenously administered SAPP $\alpha$ is both neuroprotective and neurotrophic [7] as evidenced, for example, through promoting survival of cultured neurons [8], facilitating neurite outgrowth and reducing neural damage after diffuse traumatic brain injury in rats [9]. Exogenous sAPPa improves spatial memory processes [10], and visual discrimination performance and memory retention in mice [11], while cerebrospinal fluid levels of sAPP $\alpha$ correlate with spatial memory abilities in rats [12] and in people with Alzheimer's disease [13]. Together these findings establish sAPP $\alpha$ as a regulator of neuronal and particularly memory mechanisms that may be disrupted in AD. In our studies, we have confirmed the neuroprotective actions of sAPP $\alpha$, and have also shown that acute administration of sAPP $\alpha$ increases synaptic protein synthesis [14], the expression of neuroprotective genes [15], the function of N-methyl-D-aspartate receptors and the induction of long-term potentiation [16]. We have also shown that expression of human SAPP $\alpha$, when generated by delivery of a lentivirus directly to the hippocampus in vivo, fully rescued spatial memory in the water maze and caused a partial rescue of LTP in CA1 in vitro, but without affecting plaque burden [17]. Similarly, Fol et al. found that expression of mouse SAPP $\alpha$ via adenoassociated virus 9-mediated gene transfer into APP/PS1 hippocampus rescued spatial memory, LTP and spine density, while also partially reducing the plaque load [18].
It is with great interest that historical findings of neurogenesis in the adult brain [19] have been replicated and extended over the past 50 years [20-23]. Harnessing the adult brain's neurogenic potential has been proposed to have potential for promoting recovery from a variety of brain disorders characterised by neuronal loss. However, there is now considerable evidence that adult neurogenesis has a normal and important role in cognition. There are two primary neurogenic regions in the adult brain, the subventricular zone (SVZ) lining the lateral ventricle, and the subgranular zone (SGZ) in the dentate gyrus region of the hippocampus. The dentate gyrus contributes to the processing of spatial information in the hippocampus, particularly with regards to discrimination of spatial patterns [24-26]. Intriguingly, neurons recently born in adult animals, once differentiated and connected within the dentate network, show enhanced LTP [27] and preferential incorporation into the neuronal networks storing new information [28]. In addition, conditions that reduce dentate neurogenesis, such as stress, aging or disease [29-31], also lead to deficits in spatial memory. Adult neurogenesis is impaired in mouse models of familial AD (e.g., $\left.\mathrm{APP}_{\text {swe }} / \mathrm{PS}_{\triangle \mathrm{E}} ; \mathrm{APP} / \mathrm{PS} 1\right)$, [32-34] and in humans with $\mathrm{AD}$ [23]. Based on these findings, it has been proposed that continued generation of dentate neurons is essential for the ongoing ability to perform pattern separation of spatial and other types of information, thereby facilitating memory storage elsewhere in the hippocampus $[5,35,36]$. Thus, recovery of spatial cognitive function in disease may require treatments that enhance ongoing dentate neurogenesis.

With the above considerations in mind, we sought to increase adult neurogenesis by overexpression of sAPP $\alpha$ in the dentate gyrus of APP/PS1 mice. We used adenoassociated virus 9-mediated gene transfer with a mouse sAPP $\alpha$ construct similar to that used in Fol et al. [18] to transduce cells in the dentate gyrus of wild-type (WT) and APP/PS1 mice in order to increase neurogenesis in vivo. We found that cell proliferation was decreased in the APP/PS1 mice, but this was rescued by the overexpression of sAPP $\alpha$. Survival of adult born cells, including neurons and astrocytes, was impaired in APP/PS1 mice, however sAPP $\alpha$ overexpression did not rescue this deficit. We found that sAPP $\alpha$ overexpression increased astrocytic, but not neuronal survival in the granule cell layer (GCL) of APP/PS1 mice. sAPP $\alpha$ overexpression increased astrocytic differentiation, as indicated by the percentage of adult-born astrocytes in the GCL irrespective of genotype. In contrast, neuronal differentiation was mainly unchanged in the GCL of both genotypes. sAPP $\alpha$ overexpression also reduced $\beta$-amyloid plaque burden in the dentate gyrus (DG) and cortex. 


\section{Methods}

\section{Animals}

All animal-use procedures were approved by the University of Otago Animal Ethics Committee and conducted in accordance with New Zealand Animal Welfare legislation. Adult female APP/PS1 and wild-type C57BL/6 J mice were used (average age 8 months at time of virus injection). The APP/PS1 mice on a C57BL/6J-congenic background harboured mutations in human $\mathrm{APP}_{695}$ (the Swedish mutations: K670N, M671L) and human PS1 exon nine deletion $\left(\mathrm{PS}_{\triangle \mathrm{E} 9}\right)$. Genotyping was carried out by tail tip biopsy with a PCR reaction. Mice were individually housed (post-virus injection only) at $21{ }^{\circ} \mathrm{C}$ and maintained on a $12 \mathrm{~h}$ light/dark cycle (lights on $6 \mathrm{am}$ ). All animals had access to food and water ad libitum.

\section{Viral vectors and administration}

The viral vector encoding AAV9-syn-HA-HA-sAPP $\alpha$ (mouse sequence from $\mathrm{APP}_{695}$, experimental) was commercially obtained from the University of Pennsylvania (Philadelphia, USA). The AAV9-syn-EGFP (control) vector was packaged in-house through the Otago Viral Vector Facility, Mārama platform of Brain Research New Zealand. Both viruses used the minimal human synapsin 1 promoter (syn). The plasmid containing the synHA-HA-sAPP $\alpha$ coding sequence (codon optimised for mouse) was designed locally and generated by GeneArt (Thermo Fisher) before packaging into AVV9 particles at the University of Pennsylvania. A similar (AAVp-synHA-HA-sAPP $\alpha$ ) virus has been successful in producing sustained SAPP $\alpha$ overexpression in APP/PS1 mice [18]. The AAV9-syn-HA-HA-sAPP $\alpha$ was delivered at a titre of $1 \times 10^{14} \mathrm{GC} / \mathrm{mL}$, and the control vector (AAV9-synEGFP) was administered at $1 \times 10^{12} \mathrm{GC} / \mathrm{mL}$.

Mice ( 23 female, 8 months old) were anaesthetised by inhalation of $2 \%$ isoflurane in oxygen and were placed in a stereotaxic frame (Kopf, CA, USA). A small hole was drilled directly above the injection site. A 33-gauge bevelled syringe needle (WPI, Florida, USA) was lowered to the dorsal dentate gyrus of the hippocampus with coordinates of (in mm from bregma) AP $-2, \mathrm{ML} \pm 1.4$ and DV -1.8. Mice received bilateral $1 \mu \mathrm{L}$ injections of either AAV9-HA-HA-sAPP $\alpha$ or the AAV9-EGFP virus into the DG at a rate of $0.15 \mu \mathrm{L} / \mathrm{min}$ controlled by an infusion micropump (Kopf, CA, USA). At the end of the injection, the needle was left in situ for a further $5 \mathrm{~min}$ to allow diffusion before slow withdrawal. After injection, the incision was sutured and anaesthesia was reversed by removing from isoflurane. In total, $7 \mathrm{WT}$ and $5 \mathrm{APP} / \mathrm{PS} 1$ mice were injected with the sAPP $\alpha$ virus, while $6 \mathrm{WT}$ and 5 APP/PS1 mice were injected with the EGFP control virus.

\section{Thymidine analogue injections}

The thymidine analogues, 5-chloro-2'-deoxyuridine (CldU) and 5-iodo-2'-deoxyuridine (IdU), collectively termed XdU, were used to birth-date adult born cells. Mice were injected i.p. with CldU (\#105478, MP Biomedicals, Ohio, USA) and IdU (\#100357; MP Biomedicals, Ohio, USA) at two time points using a 27-gauge needle. Six weeks following AAV9 delivery, 9.5 mo old mice received i.p. injections on one XdU $(50 \mathrm{mg} / \mathrm{kg}$ BrdU equivalent in $0.9 \%$ saline) twice a day at eight hour intervals for five days (10 total injections). Eight weeks after the last XdU injection (15 weeks after virus delivery), 11.5 mo old mice received a single i,p. injection of the other XdU (200 mg/kg BrdU equivalent). Mice were then perfused one day later. This allowed for the effect of $\mathrm{sAPP} \alpha$ treatment to discriminate between a population of newly proliferated cells ( 1 day old) and a population of mature adult-born cells (8 weeks old), the latter allowing assessment of cell survival and differentiation (Fig. 1). The protocols followed the procedures outlined in Ohline et al. [37].

In a separate preliminary experiment to assess $\mathrm{XdU}$ antibody specificity, two 2 months old C57BL/6 J mice were injected with $200 \mathrm{mg} / \mathrm{kg}$ (i.p.) BrdU equivalent of both CldU (171 mg/kg, 5 weeks before perfusion) and IdU ( $230 \mathrm{mg} / \mathrm{kg}, 2$ weeks before perfusion). These animals were studied using the procedures below for antibody specificity. The virus-injected mice were used for analysis of (1) proliferation of adult-born cells or (2) survival and differentiation of adult-born cells.

\section{Immunofluorescence procedures for adult-born cell analysis}

All animals were deeply anaesthetised by an i.p. injection of pentobarbital ( $30 \mathrm{mg} / \mathrm{mL}, 150 \mu \mathrm{l}$ per mouse). The animals were transcardially perfused with $20 \mathrm{~mL}$ of phosphate buffered saline (PBS, $0.01 \mathrm{M} \mathrm{PB}, 0.9 \%(\mathrm{w} / \mathrm{v}) \mathrm{NaCl}$ ) followed by $20 \mathrm{~mL}$ of ice-cold $4 \%(\mathrm{v} / \mathrm{v})$ paraformaldehyde (PFA) in phosphate buffer. The brain was removed and post-fixed in $4 \%$ PFA at $4{ }^{\circ} \mathrm{C}$ overnight and subsequently transferred to a $30 \%(\mathrm{w} / \mathrm{v})$ sucrose in $0.1 \mathrm{M} \mathrm{PB}$ solution for a minimum of $48 \mathrm{~h}$ for cryoprotection. Brains were then sectioned at $40 \mu \mathrm{m}$ thickness using a cryostat (Leica Biosystems, Mannheim, Germany). Free-floating sections were kept using a cryoprotectant solution containing ethylene glycol $(30 \% \mathrm{v} / \mathrm{v})$, sucrose $(30 \% \mathrm{w} / \mathrm{v})$ and phosphate buffer $(0.1 \mathrm{M})$ at $-20{ }^{\circ} \mathrm{C}$ until used for immunofluorescence imaging.

Every sixth section through the entire hippocampus (approximately 8 slices per animal) was subjected to immunofluorescence imaging and analysis as follows. Eight sections were used for the proliferation study 


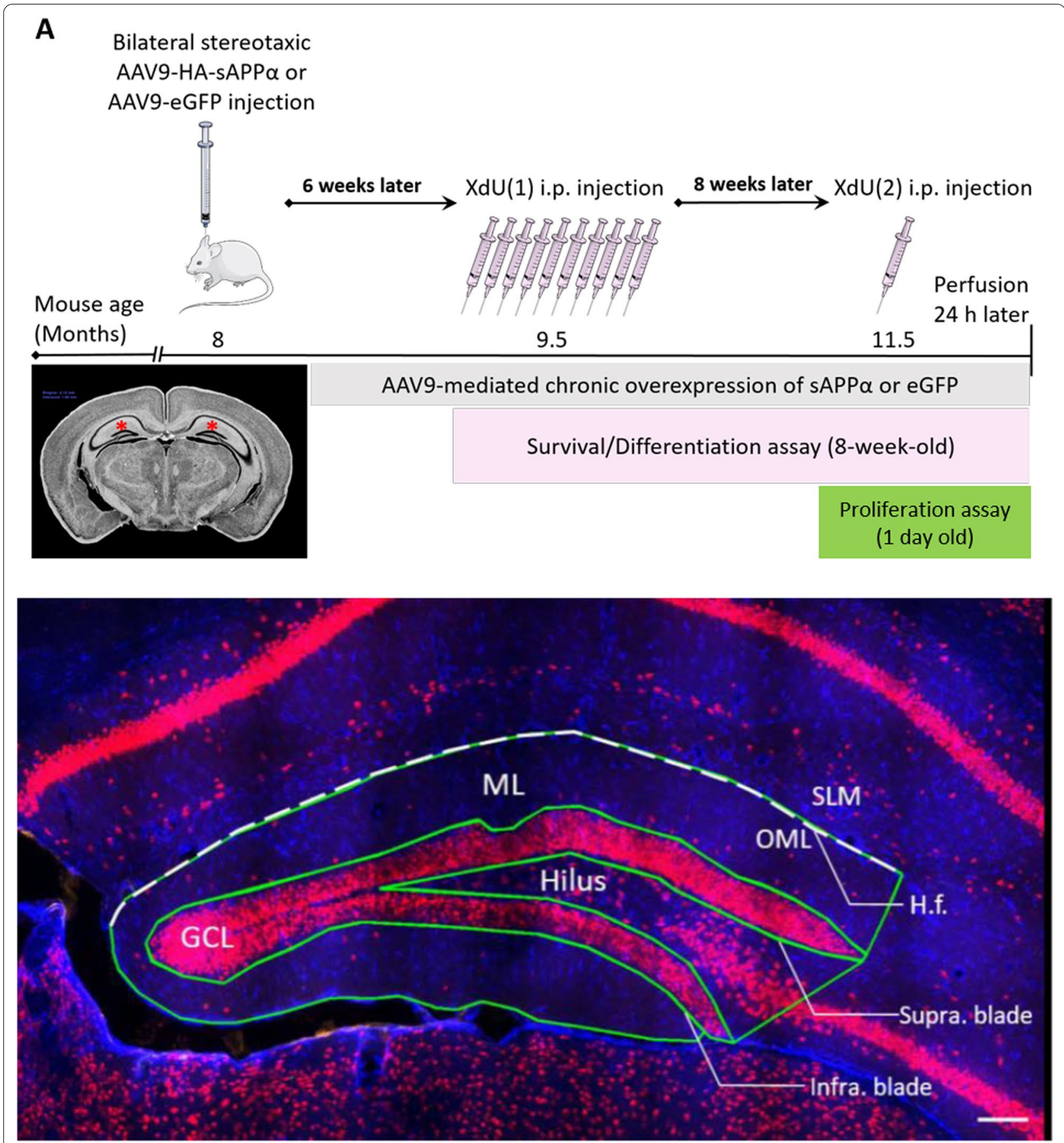

Fig. 1 Injection paradigms and definition of subregions of the dentate gyrus. A, upper panel, intrahippocampal injection paradigm for the experimental or control virus at the 8-month animal age, with all animals killed at 11.5 months of age. XdU (CldU or IdU) injections 6 weeks later were used for survival and differentiation studies, while the other XdU was injected 14 weeks post-injection for the proliferation study. B, lower panel, regions of the dentate gyrus were as outlined: ML molecular layer, H.f. hippocampal fissure, GCL granule cell layer, OML outer molecular layer, SLM stratum lacunosum moleculare, Supra blade suprapyramidal blade, Infra blade infrapyramidal blade. Scale bar: $100 \mu \mathrm{m}$

(second $\mathrm{XdU} / \mathrm{NeuN}$ ), while another eight sections were used for the survival and differentiation study (first XdU/ NeuN/GFAP). Slices were washed overnight at room temperature in Tris-buffered saline (TBS) to remove any residual cryoprotectant solution. In all cases, the slices were incubated in $2 \mathrm{M} \mathrm{HCl}$ for $1 \mathrm{~h}$ at $37^{\circ} \mathrm{C}$. Subsequently, 
boric acid (0.1 M, pH 8.5) neutralised this solution (10 min). After washing with TBS sections were blocked using a TBS containing $3 \%$ normal goat serum and $0.1 \%$ Trion-X-100 for $1 \mathrm{~h}$ at room temperature. Sections were incubated for $48 \mathrm{~h}$ at $4{ }^{\circ} \mathrm{C}$ shaking in the primary antibodies of interest, washed in the TBS Triton-X solution and then incubated for four hours with shaking in the appropriate fluorophore-conjugated secondary antibodies diluted in the blocking solution at room temperature. Slices were washed and mounted on gelatin-coated microscope slides using an anti-fade mounting solution containing glycerol $(80 \% \mathrm{v} / \mathrm{v})$ with 1,4-phenylenediamine dihydrochloride in phosphate buffer $(0.1 \mathrm{M})$. Primary antibodies were: BrdU/CldU (rat, 1:250, Abcam ab6326), BrdU/IdU (mouse, 1:250, BDSciences 347580), NeuN (guinea pig, 1:500, Synaptic Systems, 266-004), GFAP (rabbit, 1:1000, DAKO Z033401-2), 6E10 (mouse, 1:1000, BioLegend, 803002), HA-tag (mouse, 1:1000, BioLegend 901514). The secondary antibodies, all conjugated with AlexaFluor (AF) were raised in goat, were purchased from Invitrogen and had the following catalogue numbers: anti-rat (AF488, 1:500, A11006); anti-mouse (AF555, 1:500, A21414); anti-guinea pig, AF647 (1:250, A21450); anti-rabbit, (AF405, 1:500, A31556); anti-rat (AF555, 1:500, A21434).

\section{Image analysis}

Digital images of the hippocampus were captured using a Nikon Ni-E confocal microscope equipped with a Nikon C2plus camera using a $40 \times$ objective (Plan Apo: $\mathrm{N} / \mathrm{A}=0.95$; Nikon Instruments, Tokyo, Japan). Z-stacks of the DG from both hemispheres were generated using NIS-Elements, Advanced Research 4.50 software. Four excitation wavelengths were used: 405, 488, 555 and $647 \mathrm{~nm}$ (pinhole 1.2 AU). Using 1:6 sections throughout the hippocampus, 14-16 images (from 7-8 sections) were acquired using mosaic and z-stack imaging technique for each analysis. A total of $5 \mathrm{z}$-slices at $8 \mu \mathrm{m}$ intervals through the $40 \mu \mathrm{m}$ section were acquired. Care was taken to identify each cell in a single optical slice, so that it was not double-counted if it appeared in a neighbouring slice. For the antibody specificity test, across 8 slices per animal (two animals total), the number of cells labelled with rat anti-BrdU $\left(\mathrm{CldU}^{+}\right)$, cells labelled with mouse anti-BrdU ( $\left.\mathrm{IdU}^{+}\right)$and cells double-labelled with rat anti-BrdU and mouse anti-BrdU $\left(\mathrm{CldU}^{+} / \mathrm{IdU}^{+}\right)$were counted in the GCL. The percentage of $\mathrm{CldU}^{+} / \mathrm{IdU}^{+}$cells in the GCL was calculated per animal. For the proliferation assay, 14-16 z-stacks of the entire DG were analysed per mouse using Fiji/ImageJ version 1.5.3 (NIH, USA). Each $\mathrm{XdU}^{+}$cell in the SGZ was counted in optical slices from individual $z$-stacks. NeuN immunostaining was used to visualise the GCL and define the SGZ, which was set as $20 \mu \mathrm{m}$ width (approximately two granule cell widths) on either side of the margin between the GCL and hilus. A maximum intensity-projection image was rendered for each DG from the z-stacks and the length of the entire DG was measured in ImageJ to give a cell linear density of $\mathrm{XdU}^{+}$cells/mm length of DG. In a separate set of 1:6 sections through the DG for each animal, in the cell survival assay, eight-week-old $\mathrm{XdU}^{+}$cells throughout the DG, including the molecular layer (ML), the hilus and the GCL were counted in each subregion. NeuN immunostaining was used to identify the subregions. Maximum projection images of each DG were taken and the area (in $\mathrm{mm}^{2}$ ) defining each subregion was measured in ImageJ. $\mathrm{XdU}^{+}$counts per $\mathrm{mm}^{2}$ were taken for each region as an indication of cell survival. For the differentiation assay in the same sections used for the cell survival assay, nuclear XdU staining was first confirmed before each $\mathrm{XdU}^{+}$cell was individually inspected for colocalisation with NeuN for neuronal phenotype $\left(\mathrm{NeuN}^{+} / \mathrm{XdU}^{+}\right)$ or with GFAP $\left(\mathrm{GFAP}^{+} / \mathrm{XdU}^{+}\right)$for astrocytic phenotype or with neither NeuN nor GFAP $\left(\mathrm{NeuN}^{-} / \mathrm{GFAP}^{-} / \mathrm{XdU}^{+}\right)$ in optical slices from individual z-stacks. Cell counts were performed separately in three subregions of the DG: the GCL, the ML and the hilus for both hemispheres. For a cell to be considered $\mathrm{NeuN}^{+} / \mathrm{XdU}^{+}, \mathrm{XdU}^{+}$staining had to localise within the dentate $\mathrm{NeuN}^{+}$cell. Due to the localisation of $\mathrm{XdU}$ in the nucleus only $\mathrm{XdU}^{+}$cells that co-localised with $\mathrm{GFAP}^{+}$soma, but not processes across two colours were counted as double-labelled. NISElements was used in tandem with ImageJ to scan stacks of magnified single cells in the z-plane to avoid duplicate counts. All quantitative assessments were performed blinded to the experimental groups.

\section{Determination of virus-mediated expression}

To identify sAPP $\alpha$ or HA expression, brain sections (1:6 through the hippocampus) were washed in phosphate buffer $(\mathrm{PB} 0.1 \mathrm{M})$, then incubated in blocking solutions (PB containing 10\% (v/v) normal goat serum with $0.1 \%$ (v/v) Triton X-100). Sections were incubated overnight with shaking at $4{ }^{\circ} \mathrm{C}$ with primary antibodies. The following day, sections were washed with $\mathrm{PB}$, incubated with shaking for $2 \mathrm{~h}$ with shaking with secondary antibody at room temperature. Cell nuclei were counterstained with 4',6'-diamino-2-phenylindole (DAPI, Life Technologies, NZ) contained in the anti-fade mounting medium as above before adding coverslips. Sections treated with only the secondary antibody were used as a control. To examine the spread of sAPP $\alpha$ overexpression throughout the dorsal-ventral extent of the hippocampus, sections from sAPP $\alpha$-treated mice were immunolabelled with mouse anti-6E10 (sAPP $\alpha$ ) and DAPI or mouse anti-HA and DAPI. Subsequently, the spread was visualised using 
Cytation 5 (Biotek, Vermont, USA) and a $4 \times$ objective. An image of the whole slide, containing six to eight sections per mouse was scanned and captured using Gen5 Image + version 2.09 software.

\section{Congo red staining}

Slides were prepared with eight sections per APP/PS1 mouse (1:6 through the hippocampus) and Congo red was used to stain the sections to reveal amyloid plaques, with nuclei labelled with DAPI. Congo red staining and DAPI were visualised on a Nikon Eclipse Ti2 fluorescence microscope. Images of Congo red and DAPI were captured using a Nikon DC Qi2 camera, a $10 \times$ objective (Plan Apo; N/A = 0.30; Nikon Instruments, Tokyo, Japan) and NIS-Element F 4.6 software. Images were converted to 8 bit, a threshold value was determined and maintained for all images, and the percentage area covered by plaques was calculated using the ImageJ algorithm. As sAPP $\alpha$ expression was observed in the cortex overlying the hippocampus, the cortex and CA1 as well as the DG region were all analysed for plaque burden.

\section{Statistics}

All statistical analysis was performed using GraphPad Prism v8.4.3. In all cases, P-values $<0.05$ were considered significant. One animal was excluded from the Tg-control group on the basis of a Grubbs' outlier test (Alpha $=0.05$ ), as the animal displayed an abnormally high density of newly proliferated cells. Data were expressed as mean values \pm standard error of the mean (SEM). For the analysis of the linear or area density or percentage of adultborn cells, differences between groups determined using ANOVA test followed by Tukey's post-hoc test when significant main effects or interactions were detected. Dorsal and ventral data were collected from all mice; thus, a two-way repeated measure ANOVA was used to determine whether there were regional differences in adult hippocampal neurogenesis (AHN) across the longitudinal extent of the hippocampus between groups. Subsequent multiple comparisons were performed using a Sidak's post hoc test when appropriate. A two-tailed unpaired Student's $t$-test was used to compare the means of the Congo red plaque area analysis.

\section{Results}

\section{Antibody specificity}

The experimental design of the present study involved the administration of CldU and IdU at separate times to birthdate two distinct cohorts of adult-born cells within the same animal. The presence of both CldU and IdU, however, requires anti-BrdU antibodies that bind specifically to the target antigen of the injected CldU and IdU, respectively, to avoid cross-reactivity that produces non-specific staining. Therefore, we validated the specificity of the antibodies to injected CldU and IdU, respectively. The antibodies employed in this study, mouse anti-BrdU and rat anti-BrdU, were demonstrated previously to be selective for IdU and CldU, respectively [37]. However, the manufacturer of these antibodies had changed, and thus we tested the specificity of the antibodies used for this particular study.

In the WT mice injected with both CldU and IdU, both i.p., at $200 \mathrm{mg} / \mathrm{kg} \mathrm{BrdU}$ equivalent at two different time points (CldU at $5 \mathrm{wk}$ and IdU at $2 \mathrm{wk}$ before perfusion), only $4.3 \%$ of cells were double-labelled for CldU and IdU (Fig. 2D). Thus, the antibodies used to detect the injected CldU and IdU were highly specific (95.6\%) to CldU and IdU, consistent with our previously published result for the antibodies from the original manufacturer $(97 \%$ accuracy, [37]). We note that IdU gave a higher percentage of positive cells, indicative of the reduced cell death at the closer time-point (2 weeks before analysis).

\section{Confirmation of virus-mediated expression of SAPPa}

Adeno-associated viral vectors (AAV9) encoding HAtagged human sAPPa (from APP695) or control green fluorescent protein (GFP), both under the control of the neuron-specific synapsin promoter, were stereotaxically injected into the dorsal DG. This direct targeting to the dorsal DG, with sAPP $\alpha$ secreted from the expressing cells, exposed even likely non-expressing neural progenitor cells to a sAPP $\alpha$-rich environment, potentially optimising the regulation of adult hippocampal neurogenesis. Mice were housed for six weeks to ensure maximum transgene expression before the XdU mitotic marker administration to assay for adult-born cell survival/differentiation. Mice exhibited no abnormal behaviour or death during the experiment, suggesting that the sustained overexpression of sAPP $\alpha$ or EGFP was well tolerated. Immunofluorescence was performed to qualitatively assess the spread of virus-mediated expression of sAPP (indicated by $6 \mathrm{E} 10$, an antibody that binds to sAPP $\alpha$ directly) and of HA (the tag fused to sAPP $\alpha$ ) in hippocampal brain sections of AAV-HA-sAPP $\alpha$ injected mice (Fig. 3). Successful viral transduction was seen in all animals. HA expression was generally seen throughout the dorsal to ventral extent of the hippocampus (Fig. 3A), as was sAPP $\alpha$ expression (representative sections, Fig. 3B-D). In nearly all cases the spread of the viral transduction occurred through the entire hippocampus. At a minimum, the HA and sAPP $\alpha$ expression was found only in the dorsal hippocampus.

\section{Cell proliferation in the SGZ}

To determine the effect of genotype and sAPP $\alpha$ expression on cell proliferation, the linear density (cells $/ \mathrm{mm}$ ) 


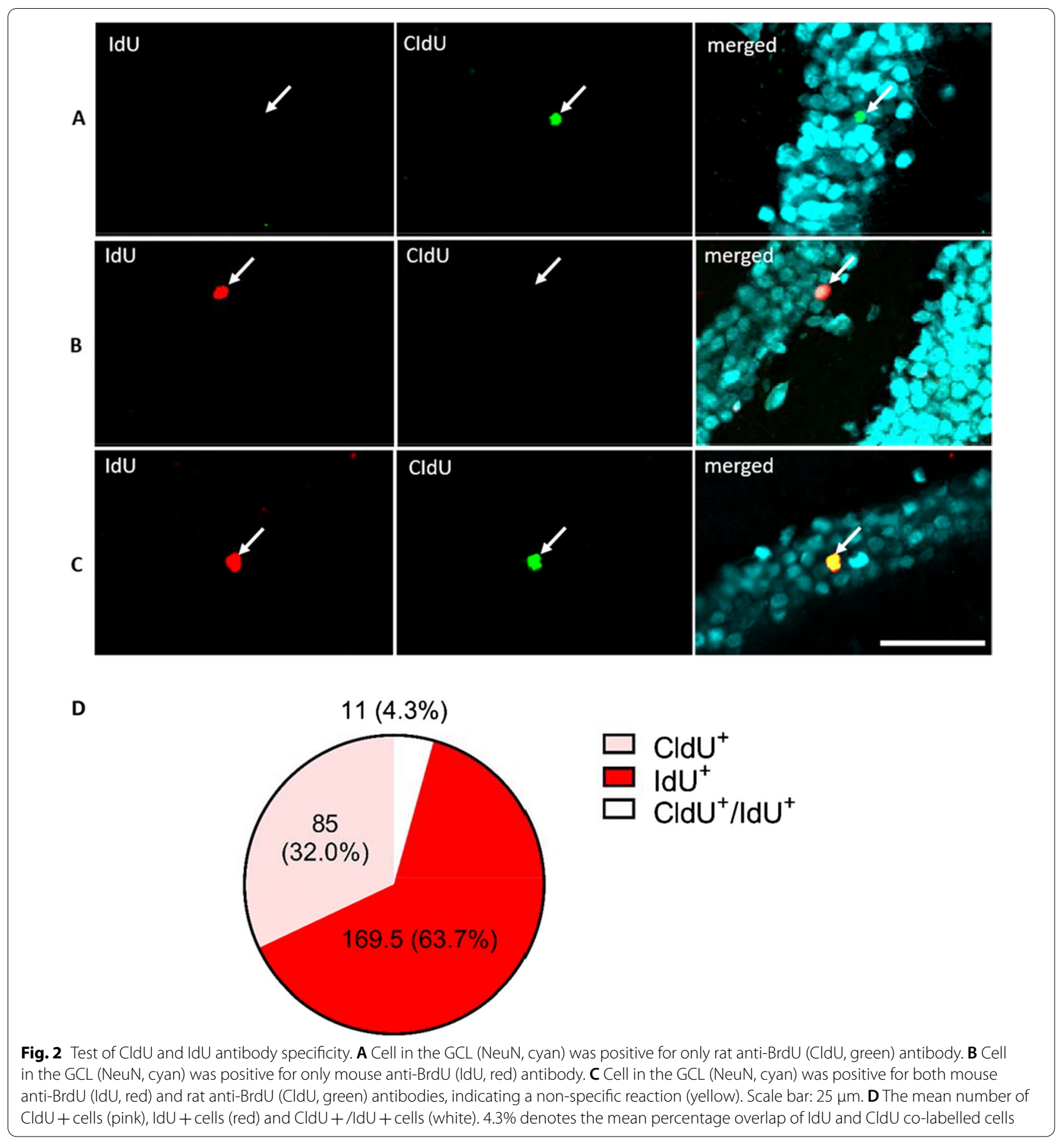

of 1-day-old $\mathrm{XdU}^{+}$cells was quantified in the SGZ. The nuclei of newly proliferated $\mathrm{XdU}^{+}$cells had similar morphology-small, irregular, and occasionally appearing in punctate clusters in both WT and Tg mice.

A two-way ANOVA revealed a significant main effect of genotype $\left(\mathrm{F}_{(1,19)}=24.67, p<0.001\right)$, indicating that $\mathrm{Tg}$ mice had a reduced linear density of $\mathrm{XdU}^{+}$cells relative to WT mice. Post-hoc analyses revealed that this overall effect was due to $\mathrm{Tg}$-control mice having a significantly reduced linear density of $\mathrm{XdU}^{+}$cells by $\sim 71 \%$ in the SGZ compared to WT-control mice (WT-control vs. Tg-control: $1.84 \pm 0.14$ vs. $0.54 \pm 0.07$ cells $/ \mathrm{mm}, t_{(19)}=7.063$, $p<0.001$; Fig. 4). 

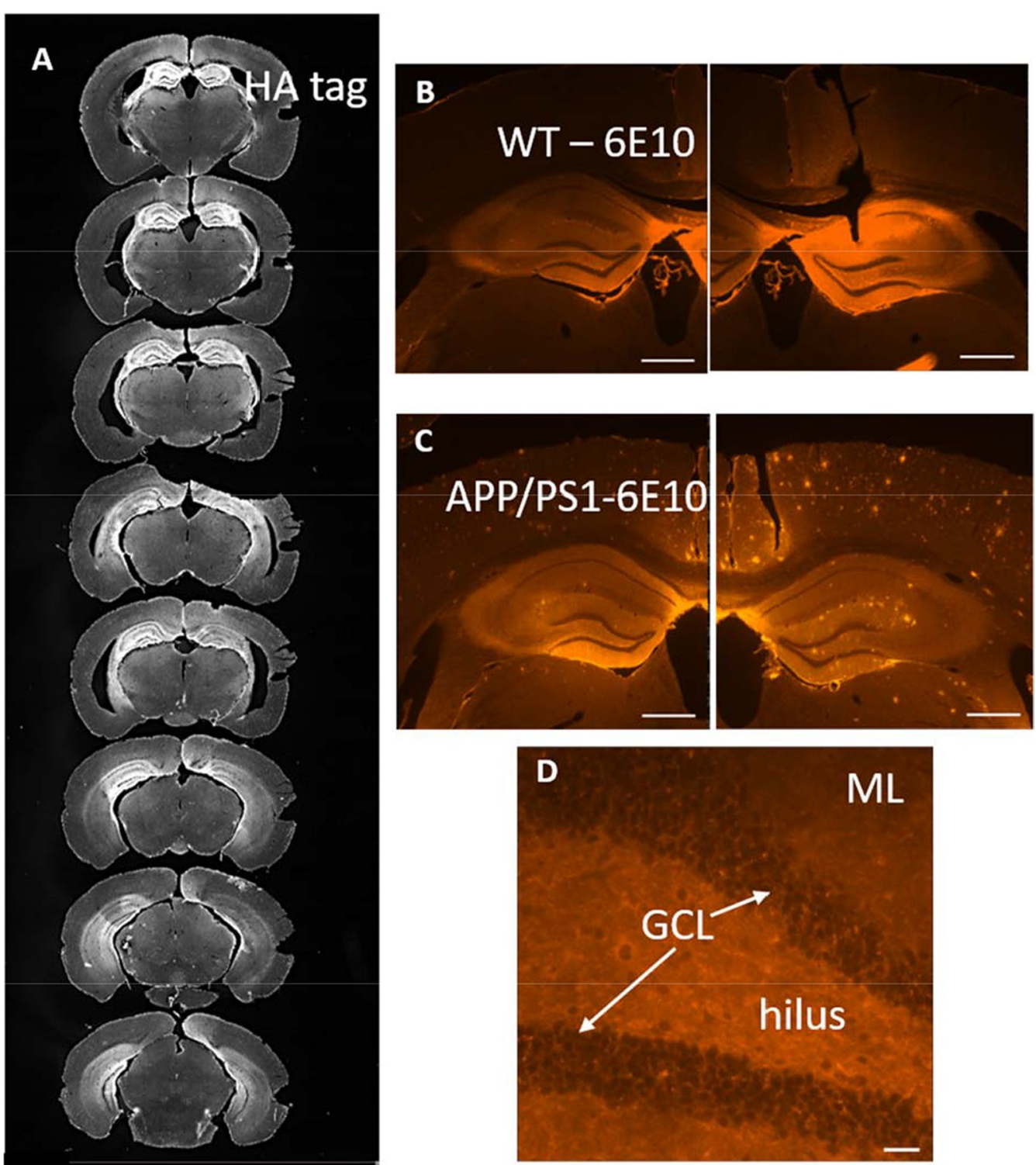

Fig. 3 Extent of HA and sAPPa expression throughout the dentate gyrus. A Representative expression of HA through the dorsal-ventral extent of the hippocampus of a virally transduced mouse. Scale bar: $5 \mathrm{~mm}$. B Representative expression of sAPPa in a wild-type mouse hippocampus labelled with the 6 E10 antibody. C Representative expression of sAPPa in an APP/PS1 mouse hippocampus also labelled with the 6E10 antibody. Note that this antibody directed against the first half of AB detects sAPPa but also labels amyloid-beta plaques. Scale bar: $1 \mathrm{~mm}$. D A $40 \times$ image of the sAPPa expression in the granule cell layer of a wild-type mouse. SAPPa is seen in cell bodies and, as expected, diffusely in the neuropil as sAPPa is expected to be secreted from the cells into the extracellular space. Scale bar: $25 \mu \mathrm{m}$

AAV-HA-sAPP $\alpha$-treated mice had a significantly increased linear density of $\mathrm{XdU}^{+}$cells compared with AAV-GFP control mice (main effect of sAPP $\alpha$; $F_{(1}$, $\left.{ }_{19)}=5.920, p=0.025\right)$. Importantly, post-hoc analyses revealed that this overall effect was due to $\operatorname{Tg}$-sAPP $\alpha$ mice having a significantly greater linear density of $\mathrm{XdU}^{+}$ cells by $\sim 150 \%$ in the SGZ compared to Tg-control mice
(Tg-control vs. Tg-sAPP $\alpha: 0.54 \pm 0.07$ vs. $1.38 \pm 0.21$ cells $/ \mathrm{mm}, t_{(19)}=4.377, p=0.028$; Fig. 4$)$. In addition, the linear density of $\mathrm{XdU}^{+}$cells in the SGZ was returned to close to the WT-control level (WT-control vs. Tg-sAPPa: $1.84 \pm 0.65$ vs. $\quad 1.38 \pm 0.21$ cells $/ \mathrm{mm}, \quad t_{(19)}=2.492$, $p=0.321)$. However, there was no effect of SAPP $\alpha$ on the proliferation of cells in the WT animals (post-hoc 


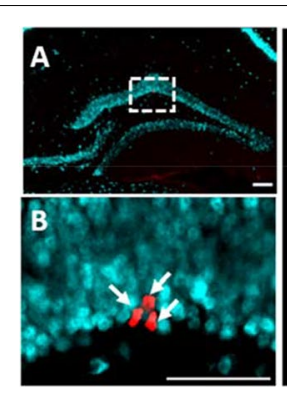

\section{c}
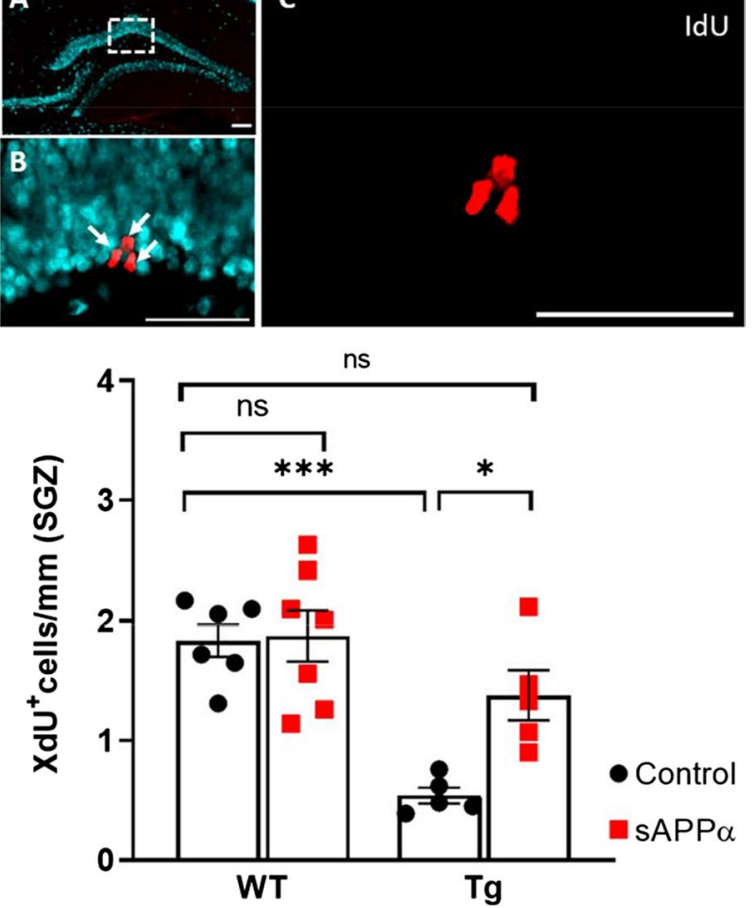

Fig. 4 sAPPa effects on cell proliferation in the subgranular zone (SGZ). A NeuN (cyan) labelled neurons in the dentate granule cell layer. Scale bar: $100 \mu \mathrm{m}$. B Insert from A showing proliferating cells (IdU, red) in the SGZ. Scale bar: $50 \mu \mathrm{m}$. C Cluster of proliferating cells (red) in the SGZ labelled by IdU, as indicated by arrows in (B). Scale bar: $50 \mu \mathrm{m}$. Bottom panel Results from sAPPa overexpression on proliferation in wild-type (WT) and Tg animals (WT-control vs. Tg-control: $1.84 \pm 0.14$ vs. $0.54 \pm 0.07$ cells $/ \mathrm{mm}$ ). ns, not significant; ${ }^{*}, p<0.05 ;{ }^{* *}, p<0.001$ assessed by two-way ANOVA followed by Tukey's post-hoc test. Data expressed as mean \pm SEM

analyses: WT-control vs. WT-sAPP $\alpha$ : $1.84 \pm 0.65$ vs. $1.88 \pm 0.25$ cells $/ \mathrm{mm}, p=0.998)$. Thus, virus-mediated $\mathrm{sAPP} \alpha$ expression rescued the cell proliferation deficit in the SGZ of Tg-control mice, without affecting proliferation in the WT mice.

\section{Survival of adult-born cells in the DG}

To determine the effect of genotype and sAPP $\alpha$ on cell survival, the area density (cells $/ \mathrm{mm}^{2}$ ) of 8-week-old adult-born $\mathrm{XdU}^{+}$cells was quantified in the GCL, ML, and hilus. Cell counts were performed in each DG subregion separately and also combined to determine adultborn cell survival in the whole DG. Immunofluorescence against $\mathrm{XdU}$ revealed mature $\mathrm{XdU}^{+}$nuclei in all groups (Fig. 5A-D).

\section{Effect of APP/PS1 genotype}

In the whole DG, there was a significantly reduced density of $\mathrm{XdU}^{+}$cells in $\mathrm{Tg}$ mice compared to WT mice (main effect of genotype $\mathrm{F}_{(1,19)}=7.034, \quad p=0.016$; Fig. 5E). This effect was due principally to significantly reduced $\mathrm{XdU}^{+}$densities in the GCL and hilus $\left(\mathrm{GCL}\left(\mathrm{F}_{(1,}\right.\right.$, 19) $=6.330, p=0.021)$; hilus $\left(\mathrm{F}_{(1,19)}=11.96, p=0.003\right.$; Fig. 5F,G), with no significant genotype main effect for the ML (Fig. 5H).

\section{Effect of sAPPa overexpression}

No main effects of $\mathrm{sAPP} \alpha$ treatment were detected on $\mathrm{XdU}^{+}$cell area density in the $\operatorname{GCL}\left(\mathrm{F}_{(1,19)}=0.004\right.$, $p=0.950), \mathrm{ML},\left(\mathrm{F}_{(1,19)}=0.6774, p=0.421\right)$, hilus $\left(\mathrm{F}_{(1,}\right.$ 19) $=0.6484, p=0.431)$, or the whole DG $\left(\mathrm{F}_{(1,19)}=0.534\right.$, $p=0.474)$. Moreover, there was no genotype $\times$ sAPP $\alpha$ treatment interaction when measured at the level of the GCL only $\left(\mathrm{F}_{(1,19)}=0.146, p=0.707\right)$ or the whole DG $\left(\mathrm{F}_{(1,}\right.$ 19) $=0.008, p=0.930)$. These results indicate that sAPP $\alpha$ overexpression did not affect the survival of adult-born cells across the 8-week survival period.

\section{Survival of adult-born neurons and astrocytes}

We also assessed the effect of genotype and sAPP $\alpha$ on the survival of specifically adult-born neurons and astrocytes by quantifying the area density of eight-week-old adultborn $\mathrm{XdU}^{+}$cells co-expressing $\mathrm{NeuN}$ or GFAP in the GCL and the whole DG, which included the GCL, ML and hilus.

\section{Effect of APP/PS1 genotype}

There was a significantly reduced neuron $\left(\mathrm{NeuN}^{+} \mathrm{XdU}^{+}\right)$ area density in the GCL (main effect of genotype $F_{(1}$, 19) $=4.804, p=0.041$; Fig. 6B). In the whole DG, however, there was no main effect of genotype $\left(F_{(1,19)}=3.392\right.$, $p=0.467$; Fig. $6 \mathrm{~A}$ ). Thus, the genotype effect on adultborn neuronal survival was confined to the GCL. Astrocyte $\left(\mathrm{GFAP}^{+} \mathrm{XdU}^{+}\right)$area density was also significantly reduced in the GCL of the Tg mice (main effect of genotype $\mathrm{F}_{(1,19)}=15.63, p<0.001$; Fig. $\left.6 \mathrm{D}\right)$. In this case, the effect was also present across the whole DG $\left(\mathrm{F}_{(1}\right.$, 19) $=6.225, p=0.022$; Fig. $6 \mathrm{C}$ ).

\section{Effect of sAPPa overexpression}

There were no main effects of sAPP $\alpha$ treatment on neuron area density in either the GCL alone $\left(F_{(1,19)}=0.001\right.$, $p=0.972$; Fig. $6 \mathrm{~B})$ or the whole DG $\left(\mathrm{F}_{(1,19)}=0.4414\right.$, $p=0.514$; Fig. $6 \mathrm{~A})$ and no interaction between genotype and sAPP $\alpha$ treatment in the GCL alone $\left(F_{(1,19)}=0.620\right.$, $p=0.441)$ or the whole DG $\left(\mathrm{F}_{(1,19)}=0.620, p=0.441\right)$. In contrast, sAPP $\alpha$ treatment caused a significant increase in astrocyte area density in the $\operatorname{GCL}\left(\mathrm{F}_{(1,19)}=4.884\right.$, $p=0.040$; Fig. $6 \mathrm{D})$, although not in the whole DG ( $\mathrm{F}(1$, $19)=0.081, p=0.779$; Fig. 6C). Taken together, these results indicate that the density of both neurons and astrocytes born 8 weeks previously was significantly 

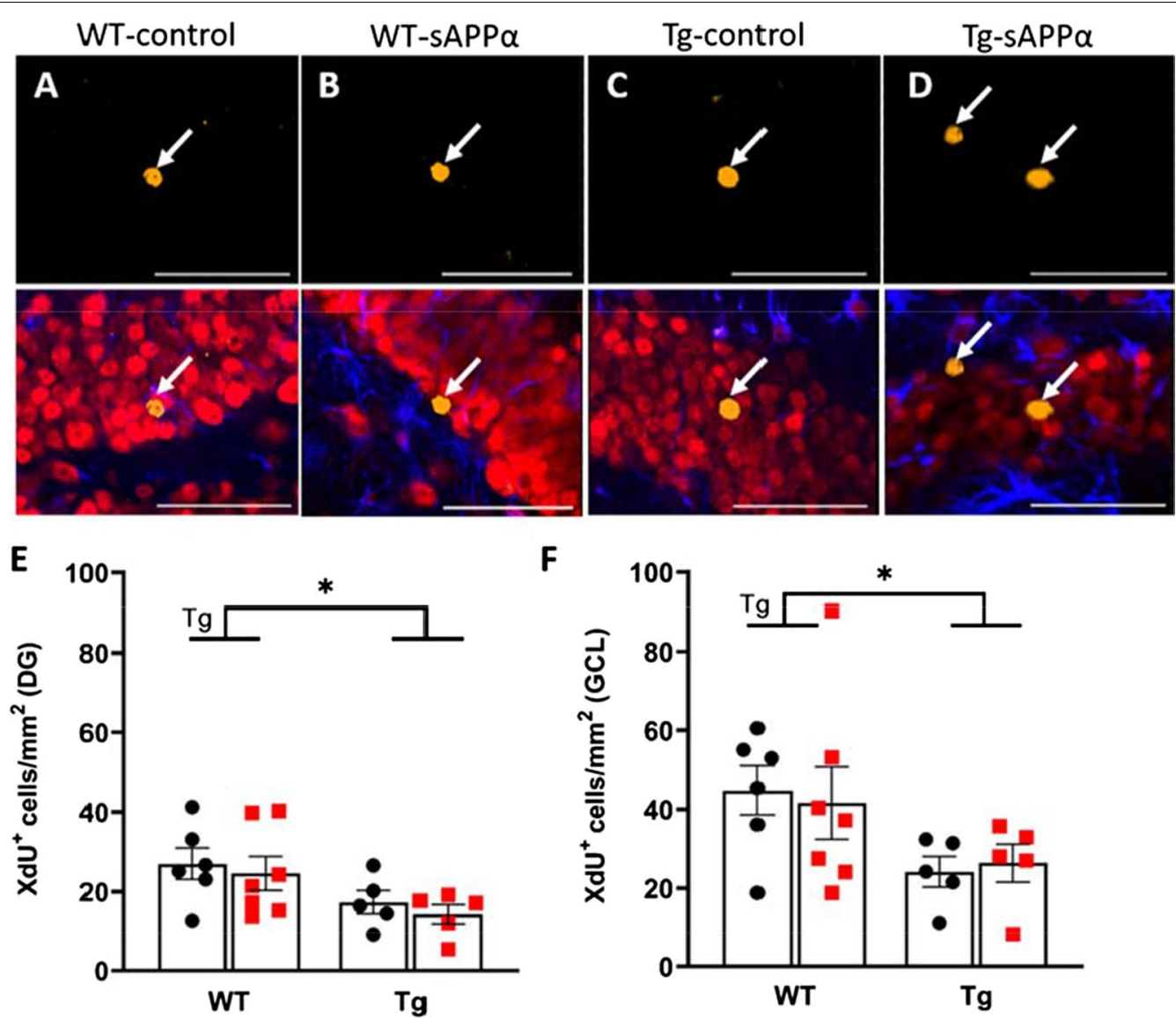

$\mathbf{F}$
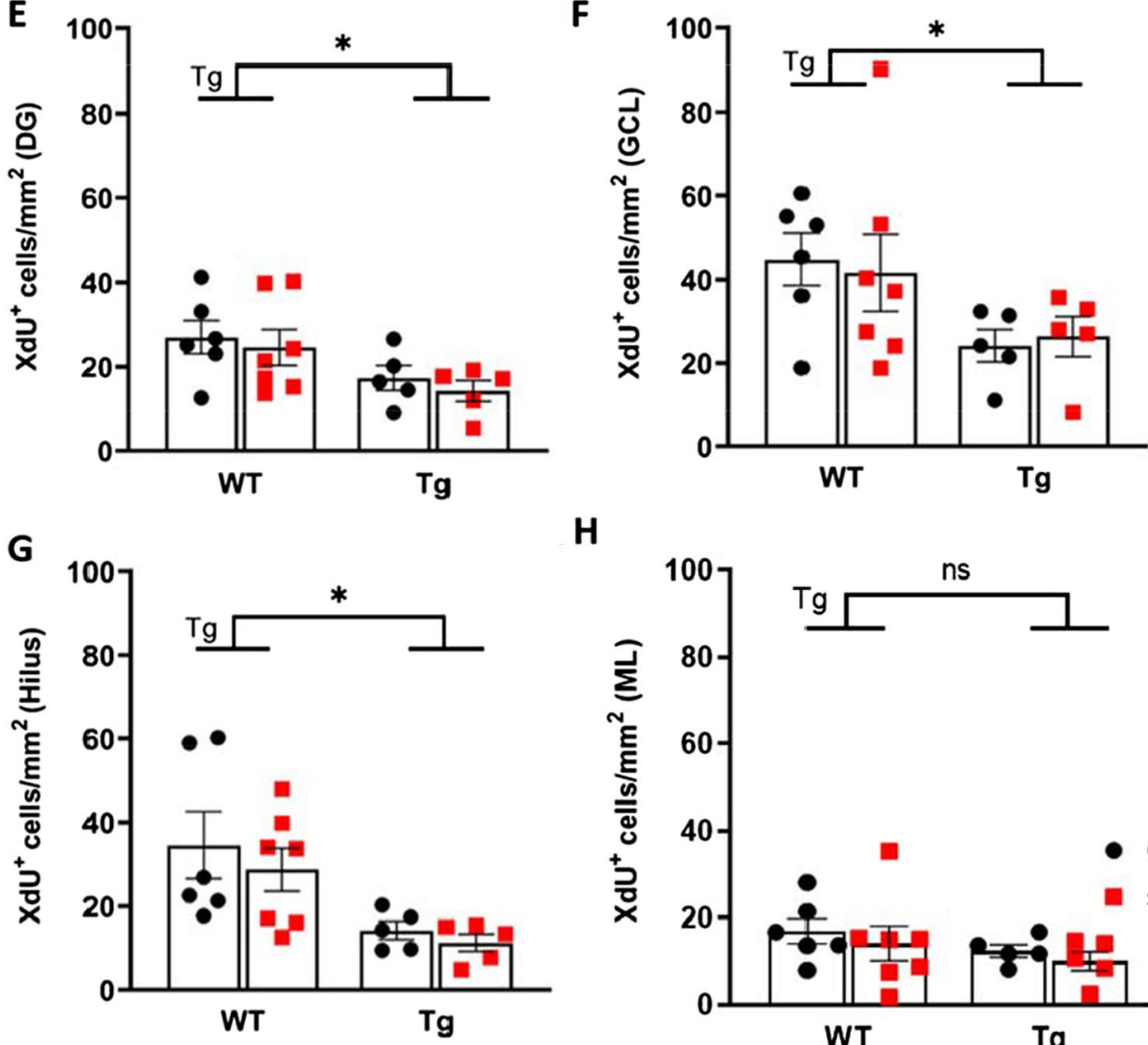

H

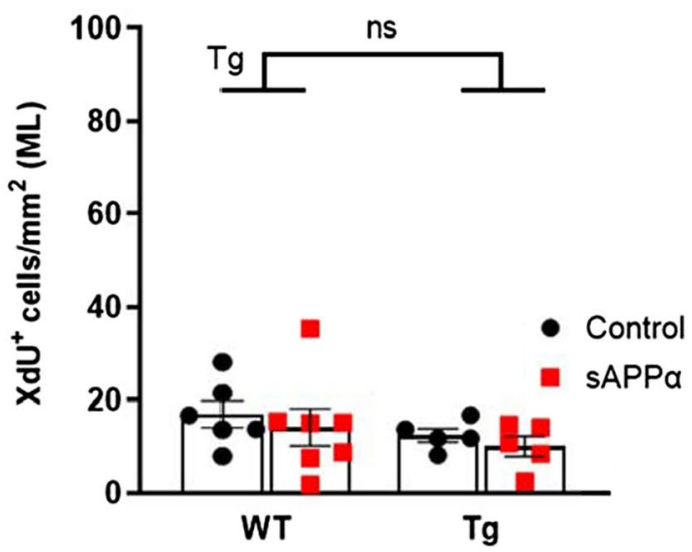

Fig. 5 sAPPa effects on cell survival in the DG. A-D top Representative optical sections of CldU immunostaining (yellow, arrows) from control (A and $\mathbf{C}$ ) and sAPPa-treated mice (B and D). A-D bottom Confocal images triple-labelled with CldU (yellow, arrows), NeuN (red, neurons) and GFAP (blue, astrocytes) in the adult DG. Scale bars: $50 \mu \mathrm{m}$. Results of the survival assay (area density of $\mathrm{XdU}^{+}$cells) in (E) the whole dentate gyrus, (F) the granule cell layer, $(\mathbf{G})$ the hilus, and $\mathbf{( H )}$ the molecular layer. Tg, main effect of genotype; SAPPa, main effect of sAPPa treatment as assessed by two-way ANOVA. * $p<0.05$. Data expressed as mean \pm SEM

reduced in the Tg mice, especially in the GCL. The genotype effect on astrocytes was maintained despite the increase caused by SAPP $\alpha$ treatment, indicating that the sAPP $\alpha$ affected both genotypes.
Differentiation of adult-born cells

To determine the effect of genotype and sAPP $\alpha$ expression on neuronal versus astrocytic differentiation, the percentage of either $\mathrm{XdU}^{+} \mathrm{NeuN}^{+} / \mathrm{XdU}^{+}$or $\mathrm{XdU}^{+} \mathrm{GFAP}^{+} / \mathrm{XdU}^{+}$cells relative to all labelled cells 

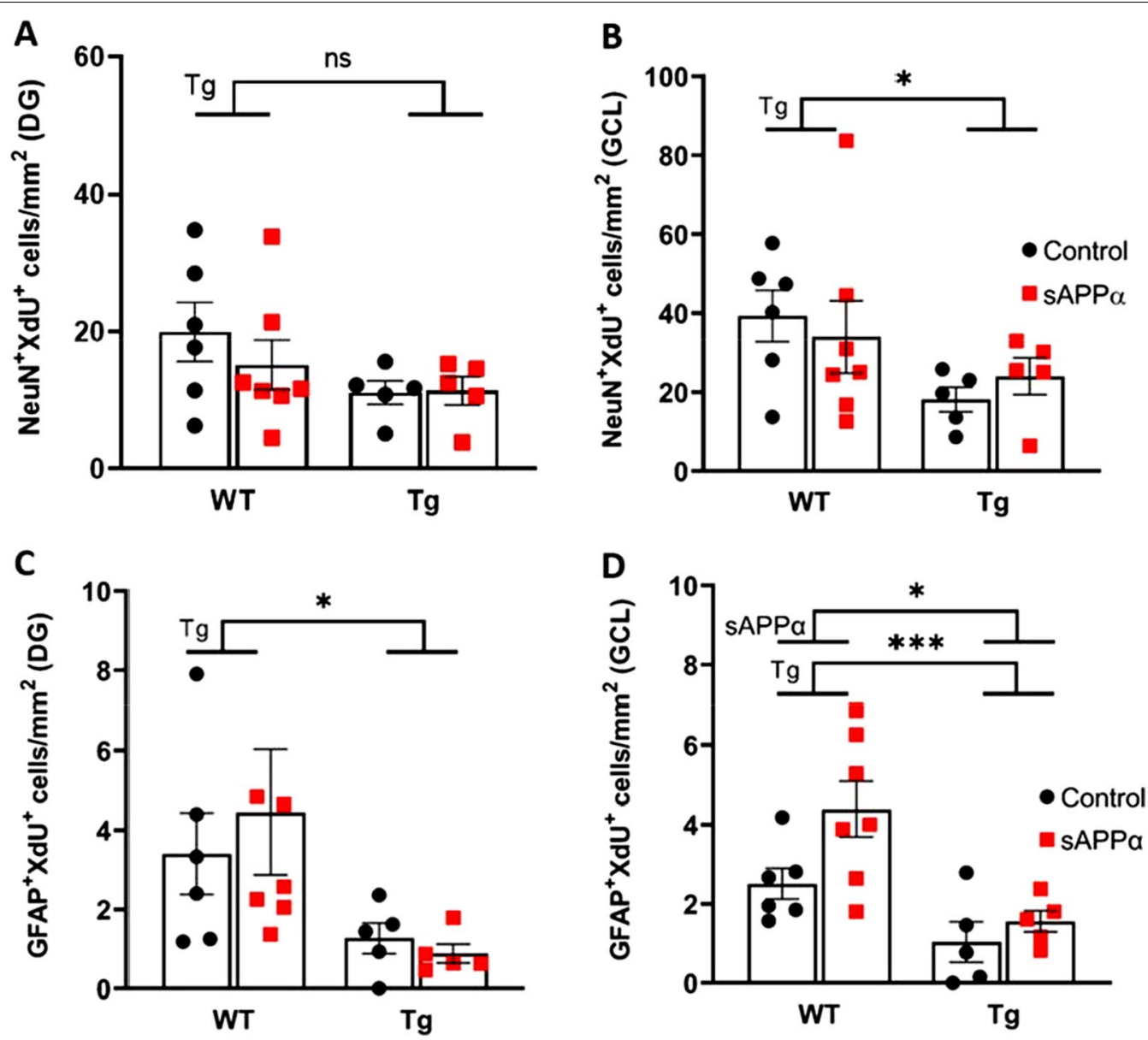

Fig. 6 sAPPa effects on cell survival in the DG. A Area density measurements of $\mathrm{NeuN}^{+} \mathrm{XdU}^{+}$cells in the whole dentate gyrus. B Area density measurements of $\mathrm{NeuN}^{+} X \mathrm{XU}{ }^{+}$cells in the granule cells layer only. C Area density measurements of $\mathrm{GFAP}^{+} X \mathrm{XU}^{+}$cells in the whole dentate gyrus. $\mathbf{D}$ Area density measurements of GFAP ${ }^{+} \mathrm{XdU}^{+}$cells in the granule cell layer only. Tg main effect of genotype, sAPPa main effect of sAPPa treatment as assessed by two-way ANOVA. $n$ s not significant; ${ }^{*} \mathrm{p}<0.05 ;{ }^{* *} \mathrm{p}<0.001$. Data expressed as mean \pm SEM

was compared between groups (Fig. 7). Double-labelling with $\mathrm{XdU}$ and NeuN revealed that the vast majority of $\mathrm{XdU}^{+}$cells in the DG became neurons in all mice, and even more so in the GCL specifically (Fig. 7D), whereas a small percentage of $\mathrm{XdU}^{+}$cells in the DG became astrocytes (Fig. 7E, F). There were also a small proportion of XdU-labelled cells that could not be identified (data not shown).

\section{Effect of APP/PS1 genotype}

There was no main effect of genotype on the percentage of neurons $\left(\mathrm{XdU}^{+} \mathrm{NeuN}^{+} / \mathrm{XdU}^{+}\right)$in the GCL alone $\left(\mathrm{F}_{(1,19)}=0.081, p=0.779\right.$; Fig. 7$)$ or the whole DG $\left(\mathrm{F}_{(1 \text {, }}\right.$ ${ }_{19)}=1.536, p=0.230$; Fig. $\left.7 \mathrm{C}, \mathrm{E}\right)$. In contrast, there was a strong trend toward a decrease in the percentage of astrocytes $\left(\mathrm{XdU}^{+} \mathrm{GFAP}^{+} / \mathrm{XdU}^{+}\right)$in the $\mathrm{GCL}$ in the $\mathrm{Tg}$ mice, $\left(\mathrm{F}_{(1,19)}=4.206, p=0.054\right.$; Fig. $\left.7 \mathrm{~F}\right)$, and a significant decrease in the whole DG $\left(\mathrm{F}_{(1,19)}=6.766, p=0.018\right.$;
Fig. 7E). Together these results indicate that astrocytic differentiation was reduced in the whole DG of Tg mice compared to WT mice irrespective of sAPP $\alpha$ treatment.

\section{Effect of sAPPa overexpression}

There were no main effects of SAPP $\alpha$ treatment on the percentage of neurons in the GCL only $\left(\mathrm{F}_{(1,19)}=0.448\right.$, $p=0.511$; Fig. 7D) or the whole DG $\left(\mathrm{F}_{(1,19)}=0.086\right.$, $p=0.773$; Fig. 7C). However, there was a significant interaction between genotype and SAPP $\alpha$ treatment specifically in the whole DG $\left(\mathrm{F}_{(1,19)}=4.685, p=0.043\right)$. Thus, SAPP $\alpha$ expression tended to increase neuronal differentiation in Tg mice but to decrease it in WT mice in the whole DG (Fig. 7C), an effect mostly in areas outside of the GCL. For astrocytes, there was a small but significant increase in relative expression for the sAPP $\alpha$-treated mice in the GCL alone $\left(\mathrm{F}_{(1,19)}=7.354, p=0.014\right.$; Fig. $\left.7 \mathrm{~F}\right)$, but not in the whole DG $\left(\mathrm{F}_{(1,19)}=2.609, p=0.123\right.$; Fig. $\left.7 \mathrm{E}\right)$. 

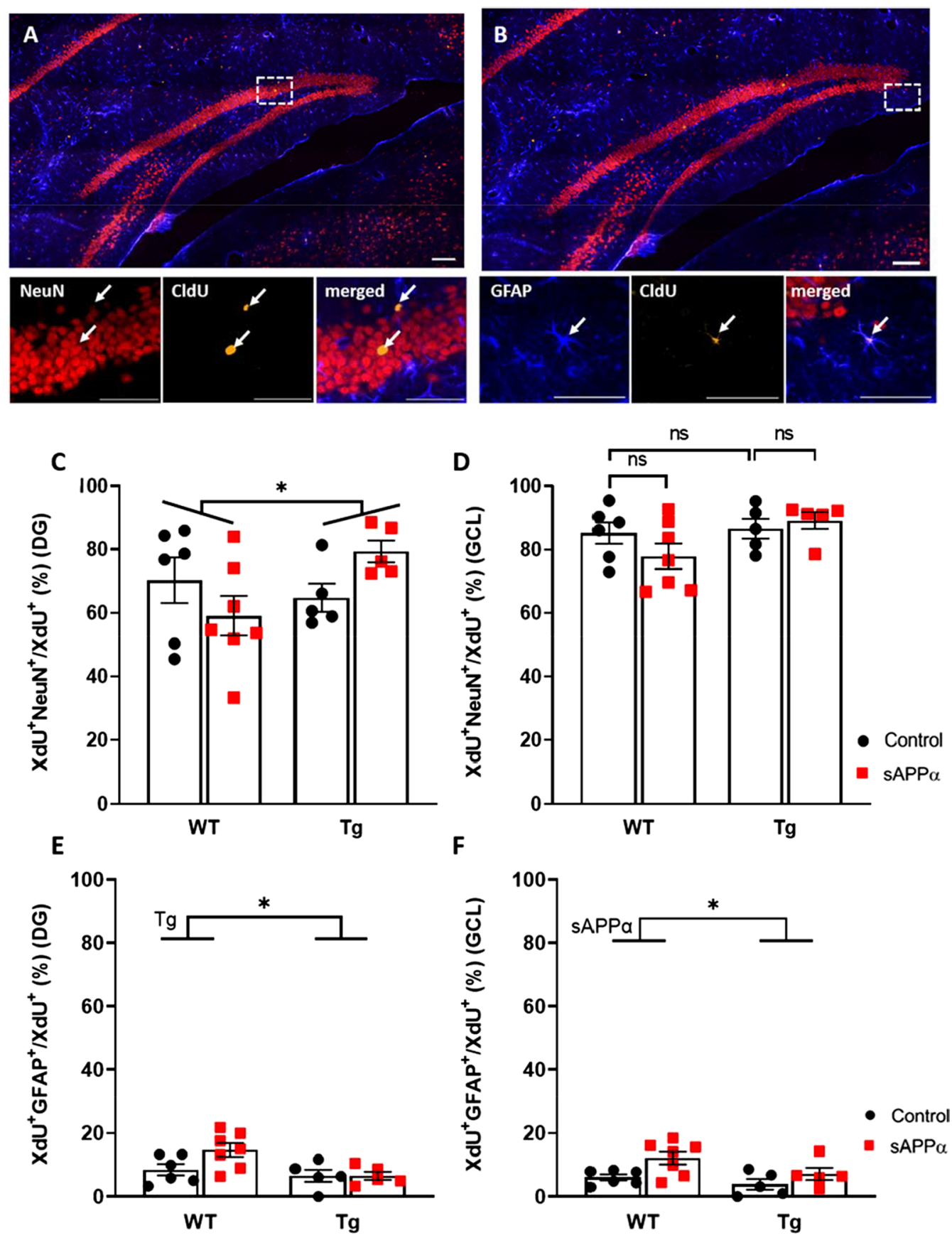

Fig. 7 sAPPa effect on cell differentiation. A A representative mosaic confocal image of the dentate gyrus. For all images NeuN is red, GFAP is blue and CldU is yellow. Scale bar: $100 \mu \mathrm{m}$. A, below From the top left insert: NeuN labelling, CldU labelling, and merged image showing two NeuN + CldU + cells. Scale bar: $50 \mu \mathrm{m}$. B A representative mosaic confocal image of the dentate gyrus. Scale bar: $100 \mu \mathrm{m}$. B, below From the top right insert: GFAP labelling CldU labelling, and merged image showing two GFAP + CldU + cells. Scale bar: $50 \mu \mathrm{m}$. C Results of the differentiation assay for neurons in the whole dentate gyrus of WT and Tg animals. There was a significant APPa treatment $\times$ genotype interaction, ${ }^{*}, \mathrm{p}<.05$. D Results of the differentiation assay for neurons in the granule cell layer of WT and Tg animals. E Results of the differentiation assay for astrocytes in the whole dentate gyrus of WT and Tg animals. F Results of the differentiation assay for astrocytes in the granule cell layer of WT and Tg animals. Tg, main effect of genotype; SAPPa, main of SAPPa treatment as assessed by 2-way ANOVA. ns not significant, ${ }^{*} p<.05$. Data expressed as mean \pm SEM 
Unlike for neuronal differentiation, there was no significant genotype $\mathrm{x}$ SAPP $\alpha$ interaction for the percentage of astrocytes in the whole DG $\left(\mathrm{F}_{(1,19)}=3.151, p=0.092\right)$. A

Table 1 Summary of the main effects of genotype and SAPPa treatment and their interaction on cell differentiation

\begin{tabular}{llllll}
\hline \% Differentiation & \multicolumn{2}{l}{ Neuronal } & & & Astrocytic \\
\cline { 2 - 3 } \cline { 5 - 6 } Dependent variable & Genotype & sAPPa & & Genotype & sAPPa \\
\hline GCL & $=$ & $=$ & & $\uparrow^{*}$ \\
DG & $=$ & $\uparrow / \downarrow^{a}$ & & $\downarrow^{*}$ & $=$ \\
\hline
\end{tabular}

$\downarrow$ denotes reduction; $\uparrow$ denotes increase; $=$ denotes no change. ${ }^{\text {a Denotes an }}$ interaction between genotype and SAPPa treatment whereby sAPPa tended to increase neuronal differentiation in Tg mice but to decrease it in WT mice. ${ }^{*} p<.05$. The DG was comprised of the GCL, ML and hilus summary of the main findings for adult-born neuronal and astrocytic differentiation is presented in Table 1.

Effect of sAPPa overexpression on amyloid plaque burden The amyloid plaque burden was evaluated in the whole DG, CA1, and overlying sensorimotor cortex by Congo red staining. Plaque deposition was more abundant in the ML and hilus compared to the GCL (Fig. 8A, B), which is consistent with our observations in a different APP/ PS1 mouse strain [17]. The percentage plaque-covered area was significantly reduced in Tg-sAPP $\alpha$ mice by $24 \%$ in the DG (Tg-control vs. Tg-sAPP $\alpha$ : $0.80 \pm 0.08 \%$ vs. $0.61 \pm 0.08 \%, t_{(8)}=2.317, p=0.049, \mathrm{n}=5$ per group) and by $20 \%$ in the cortex (Tg-control vs. Tg-sAPP $\alpha$ : $0.65 \pm 0.05 \%$ vs. $0.52 \pm 0.05 \%, t_{(8)}=2.518, p=0.036, \mathrm{n}=5$ per group; Fig. 8E). Few plaques were detected in the $\mathrm{CA} 1$ region and the percentage of plaque area in CA1
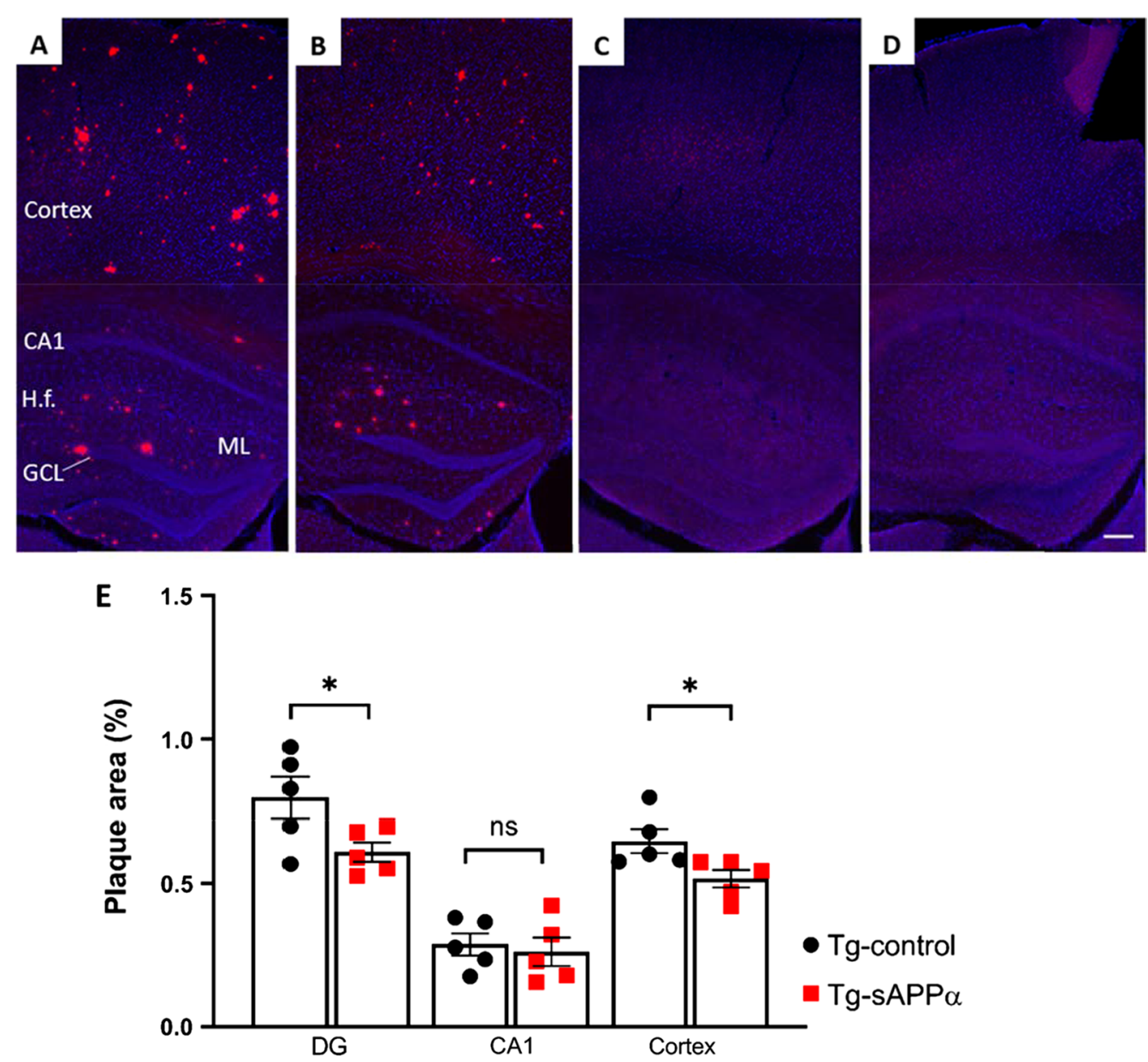

Fig. 8 sAPPa effects on amyloid plaque load. Amyloid plaques (Congo red) were specific to Tg-control (A) and Tg-sAPPa (B) mice at 11.5 months of age in the hippocampus and cortex (DAPI nuclei, blue). No amyloid plaques were present in WT-control (C) and WT-sAPPa (D) mice the same age. Scale bar: $100 \mu \mathrm{m}$. H.f. Hippocampal fissure. E Percentage of area covered by plaques measured across the dentate gyrus, CA1 and the somatosensory cortex for the Tg-control and Tg-SAPPa overexpressing mice. ns not significant, ${ }^{*}, p<0.05$ assessed unpaired Student's $t$-test. Data expressed as mean \pm SEM 
was not different between Tg-control and Tg-sAPP $\alpha$ mice (Tg-control vs. Tg-sAPP $\alpha$ : $0.29 \pm 0.06 \%$ vs. $0.26 \pm 0.06 \%$, $\mathrm{n}=5$ per group, $t_{(8)}=0.4104, p=0.692$; Fig. $8 \mathrm{E}$ ). No amyloid plaques were detected in the hippocampus or cortex of WT-control (Fig. 8C) and WT-sAPP $\alpha$ mice (Fig. 8D).

\section{Discussion}

This study set out to investigate whether adult hippocampal genesis of neurons and astrocytes was impaired in an APP/PS1 AD mouse model and, if so, whether any effects could be rescued by AAV-mediated sAPP $\alpha$ overexpression. First, it was important to determine the extent to which the AAV9-HA-HA-sAPP $\alpha$ virus transduced cells in the dentate gyrus. All injected AAV9-HA-HA-sAPP $\alpha$ mice exhibited prominent sAPP $\alpha$ and HA expression around the cell bodies located in the GCL and hilus of the DG, indicating high transduction efficiency that was consistent with that found by Fol et al. [18]. AAV9 achieved a greater spread of sAPP $\alpha$ compared to the more restricted spread using a lentiviral vector, as employed by Tan et al. [17]. All AAV-HA-HA-sAPP $\alpha$ injected mice also exhibited similar patterns of sAPP $\alpha$ within the CA1-3 subfields, most notably in proximal CA3 pyramidal cells. AAV-HA-HA-sAPP $\alpha$ spread through the dorsal-ventral extent of the hippocampus, even though the injection site was in the dorsal hippocampus only. Long-term expression of sAPP $\alpha$ was driven by the synapsin promoter, permitting sAPP $\alpha$ to be expressed exclusively in neurons. Although not quantified in the present study, Fol et al. demonstrated with a similar virus (although with two injection sites) that, four weeks after injection, a significant threefold increase in SAPP $\alpha$ expression was found in the virally transduced animals relative to the endogenous sAPPa in WT mice [18]. As an additional advantage, sAPP $\alpha$ is secreted from cells, so its effects on cells could have been throughout the entire region in which it was present and may well have included effects on astrocytes and other cell types within the DG such as neural progenitor cells.

\section{Rescue of cell proliferation by SAPPa in APP/PS1 mice}

Adult hippocampal neurogenesis studies utilising transgenic mouse models of AD have consistently shown that the adult hippocampal cell proliferation is impaired [3841]. Thus, cell proliferation in the SGZ was hypothesised to be decreased in APP/PS1 mice compared to WT mice in the present study. Consistent with this hypothesis, APP/PS1-control mice displayed a $71 \%$ reduced linear density of newly proliferated cells in the SGZ compared to the WT-control mice. This decrease may have been due to a reduction in the number of activated stem cells and therefore, the synthesis of progenitors. Additionally, production of $A \beta$ soluble aggregates may have decreased the rate of cell cycle completion by increasing the cell cycle length. While a small number of studies reporting increased AHN $[42,43]$ in AD mouse models attributed their findings to differences in genetic backgrounds and transgene expressions and the timing of aberrant AHN in relation to the neuropathology stage, the currently observed cell proliferation deficit at 11.5 months of age is consistent with previous findings of impaired cell proliferation in the SGZ of APP/PS1 mice from as early as $1-2$ months [44], by 3 months [45], by 6 months [46] and between 8-9 months of age [47].

We found that SAPPa overexpression significantly increased cell proliferation in the SGZ of the Tg mice by $150 \%$ but not in the WT mice, producing a nearfull rescue of cell proliferation in the $\mathrm{Tg}$ - SAPP $\alpha$ mice. Whether this increase in proliferation in the APP/PS1 mice was due to an expansion of the proliferative pool and synthesis of progenitors, or a faster rate of cell cycle completion could not be distinguished in the present study.

sAPP $\alpha$ has been shown to stimulate the proliferation of adult NPC in the SVZ in normal animals in an epidermal growth factor and basic fibroblast growth factordependent [48] or independent manner [49]. The lack of effect in the SGZ in these studies is consistent with our lack of effect in the WT-control animals. Also consistent with this study, sAPP $\alpha$ has been demonstrated to rescue proliferation deficits induced by $\beta$-secretase inhibition [49] and ageing [50], indicating that SAPP $\alpha$ can enhance proliferation under impairment conditions, both with reduced $A \beta$ and in the presence of increased $\mathrm{A} \beta$ burden. While the effect of sAPP $\alpha$ on the cell division process may be relatively direct, it is noteworthy that endogenous $A \beta$ plays a causal role in impairing proliferation in early AD [51] and that sAPP $\alpha$ can reduce the $A \beta$ plaque burden in the DG (Fig. 8; [18]). Overexpression of sAPP $\alpha$ may thus have reduced $A \beta$-mediated interference of levels of endogenous sAPP $\alpha$ and other growth factors, leading to improvements in the brain environment [18], including the neurogenic environment that promoted cell proliferation. sAPP $\alpha$ overexpression would have restored and raised sAPP $\alpha$ levels in the local environment, making it more conducive for expansion of the progenitor pool.

The lack of proliferative effects in WT mice may be related to the degree of sAPP $\alpha$ overexpression. In neurospheres from normal rats, sAPP $\alpha$ dose-dependently increased cell proliferation over a range of concentrations (0.01-1 nM) [52]. However, these experimental conditions were different from the present study in whole animals. Given the myriad of known beneficial effects of sAPP $\alpha$ [53], it was intuitive to infer this excess would be promising for AHN in a WT mouse. However, in assays of neurogenesis, neuroprotection and synaptic plasticity, 
sAPP $\alpha$ confers benefit only at low concentrations $[8,52$, 54]. For example, there was an inverted-U shaped dosedependent rescue of proliferation deficits in adult mouse SVZ-derived neurospheres [49]. Thus, a plausible explanation for the observed lack of effect on SGZ proliferation in WT- sAPP $\alpha$ mice is that sAPP $\alpha$ overexpression was on a background of an already optimal concentration of sAPP $\alpha$ in the tissue.

\section{Failure of SAPPa to rescue cell survival in APP/PS1 mice}

Survival of adult-born cells, in particular neurons and astrocytes, was hypothesised to be decreased in APP/ PS1 mice compared to WT mice. Consistent with the hypothesis, 8-week-old adult-born $\mathrm{XdU}^{+}$cell area density was reduced in the DG of APP/PS1 mice compared to WT mice, irrespective of sAPP $\alpha$ treatment. The same effect was also apparent for both neurons and astrocytes as independently assessed. This apparent impairment in adult-born cell survival is consistent with a previous report in the DG of APP/PS1 mice [39]. However, given the reduced cell proliferation in 11.5 months old APP/PS1 mice in the present study, the reduced survival of adult-born cells including neurons and astrocytes in APP/PS1 mice might be at least partially due to a decreased cell proliferation at the time of injection (i.e. 9.5 months). Whether the decline in cell proliferation at 9.5 months of age was as strong as the $71 \%$ reduction in cell proliferation in Tg-control mice that we measured at 11.5 months of age is not known. But since the total cell survival declined by less than $50 \%$ in the whole DG, a prediction from this study is that proliferation was not as badly affected at the earlier age of 9.5 months, unless there was some compensatory increase in cell survival mechanisms that offset a more extensive decline in cell genesis. As a future study, $\mathrm{DCX}^{+} / \mathrm{XDU}^{+}$or $\mathrm{NeuN}^{+} /$ $\mathrm{XdU}^{+}$cells could also be examined 3-4 weeks post-injection, as this is a time when the adult-born cells play a particularly important role in certain memory tasks. After this up to $50 \%$ of cells do not survive past 3-4 weeks post-birth due to apoptosis, which may influence our analysis of survival rates at 8 weeks.

Despite its rescue of cell proliferation in the $\mathrm{Tg}$ mice, SAPP $\alpha$ overexpression failed to rescue the survival of $\mathrm{XdU}^{+}$-labelled cells or neurons specifically but, interestingly, there was a significant increase in the area density of astrocytes in the GCL across both genotypes. Whether this is due to a protection of astrocyte survival post-genesis by sAPP $\alpha$, as suggested in a neurosphere study [52], or a delayed migration of astrocytes outside of the SGZ/ GCL area remains to be determined.

\section{Neuronal versus astrocytic differentiation}

We also investigated whether the percentage of cells differentiating into neurons or astrocytes showed genotype or treatment effects. Overall, there was no change in the percentage of 8-week-old adult-born neurons $\left(\mathrm{XdU}^{+} \mathrm{NeuN}^{+} / \mathrm{XdU}^{+}\right)$in the GCL or the whole DG of APP/PS1 and WT mice irrespective of sAPP $\alpha$ treatment. In contrast, previous studies demonstrated impaired neuronal differentiation in APP/PS1 mice, as indicated by a reduced proportion of $\mathrm{BrdU}^{+} \mathrm{NeuN}^{+} / \mathrm{BrdU}^{+}$cells in the 6 mo old DG [39] and reduced number of $\mathrm{DCX}^{+} / \mathrm{BrdU}^{+}$ cells in the 9 mo old SGZ [44]. This result however is consistent another study of these mice at 10 months of age for which there was no change in the total number of $\mathrm{DCX}+$ cells[55], and consistent with studies in other AD mouse models showing no effect on neuronal differentiation $[41,56]$. A possible explanation for these inconsistencies might be variations in $A \beta$ pathology within the $A D$ animal models.

sAPP $\alpha$ overexpression was hypothesised to enhance neuronal and/or astrocytic differentiation in sAPP $\alpha$ treated mice, based on in vitro observations that sAPP $\alpha$ can promote neuronal differentiation $[57,58]$ and astrocytic differentiation [52] of NPCs. It is notable then that sAPP $\alpha$ overexpression modestly increased astrocytic differentiation, as indicated by the percentage of adult-born astrocytes in the GCL irrespective of genotype, supporting the notion that within the progenitor cell pool, sAPP $\alpha$ promoted astrocyte-committed progenitors to terminally differentiate. Notably, recent studies have emphasised the importance of astrocytes to learning and memory in the hippocampal formation [59], and thus sAPP $\alpha$ overexpression resulting in increased astrocytic differentiation might have contributed to memory enhancement seen in previous studies $[17,18]$. In contrast, neuronal differentiation was mainly unchanged in the GCL of both genotypes, consistent with a previous finding that $\mathrm{sAPP} \alpha$ treatment did not affect the number of neurons $\left(\mathrm{MAP}^{+}\right.$ or calbindin ${ }^{+}$) generated from SGZ-derived WT NPCs in vitro [52]. However, in the whole DG, there was a significant interaction between genotype $\mathrm{x}$ sAPP $\alpha$ treatment, suggesting that $\mathrm{SAPP} \alpha$ overexpression tended to increase neuronal differentiation in APP/PS1 mice but to decrease it in WT mice.

Over $70 \%$ of $\mathrm{XdU}^{+}$cells were identified as neuronal cells in the whole DG of the WT-control animals and over $80 \%$ in the GCL, roughly in accord with other rodent $[60,61]$ studies which report $~ 80 \%$. Eight percent of cells were identified as astrocytes at eight weeks in the DG of WT-control mice, similar to rodent studies reporting $7 \%[62,63]$. This left an average of $22 \%$ of $\mathrm{XdU}^{+}$ cells expressing neither NeuN nor GFAP in the whole DG across groups, also consistent with previous reports 
of $20 \%[60,64,65]$. Recent studies suggest that unidentified $\mathrm{XdU}^{+}$cells could be microglia, which can arise from progenitor cells [66]. The unidentified $\mathrm{XdU}^{+}$cells in this study were included in the total number of $\mathrm{XdU}^{+}$cells used for differentiation analysis and thus influenced overall neuronal and astrocyte proportions. Future studies are needed to include co-staining with markers of oligodendrocytes and microglia alongside assessing morphology to at least preclude these glial cell types. Another possibility is that these $\mathrm{XdU}^{+}$cells are potential neurons or astrocytes, remaining undifferentiated until their function is determined at a later time $[67,68]$. However, as no differences were found in the area density of unidentified $\mathrm{XdU}^{+}$cells in the GCL between any groups, the distribution of these cells did not contribute significantly to the present results.

\section{Amelioration of $A \beta$ plaque load}

As expected, a significant $A \beta$ plaque load was observed in the hippocampus and cortex of the 11.5 mo old APP/ PS1 mice compared to WT mice, where no deposits were found. sAPPa's anti-amyloidogenic properties via direct and indirect inhibition of $\beta$-secretase have previously been demonstrated $[18,69,70]$. Consistent with these findings, SAPP $\alpha$ overexpression resulted in a significant reduction in $A \beta$ plaque load in the DG and cortex, indicating that sAPP $\alpha$ overexpression reduced not only $\mathrm{A} \beta$ plaque area in the treated hippocampus but also adjacent cortical areas. These findings are in agreement with Fol et al., who reported a significantly reduced plaque area in the cortex and hippocampus as well as a comparable $33 \%$ reduction of human $A \beta 42$ species in these areas [18]. This result and the present one can be attributed to efficient diffusion of small AAV-HA-HA-sAPP $\alpha$ particles throughout the hippocampus as well as from the needle tract to the overlying cortex [71]. Another possibility is that secreted SAPP $\alpha$ diffused through the brain parenchyma [18]. There was no significant change in plaque area in the CA1, most likely a result of the small number of plaques in both $\mathrm{Tg}$-control and $\mathrm{Tg}$-s APP $\alpha$ mice in this region.

A potential mechanism by which sAPP $\alpha$ attenuated the plaque burden was by microglia recruitment, as indicated by the previously reported increased expression of plaque-associated microglia and expression of Triggering Receptor Expressed on Myeloid' cells (TREM), and of the microglial proteases neprilysin and insulin-degrading enzyme in AAV-HA-HA-sAPP $\alpha$ mice [18]. Although not tested in the present experiments, these prior data suggest that in the present study $\mathrm{SAPP} \alpha$ may have helped recruit microglia into the vicinity of amyloid plaques, potentially enhancing $A \beta$ and plaque clearance (Additional file 1).

\section{Conclusion}

This is the first study to assess the effect of in vivo sAPP $\alpha$ overexpression on adult hippocampal neuroand astrogenesis in an AD mouse model. We observed a rescue of the APP/PS1 deficit in proliferation of adult born cells, an increase in astrocytic differentiation in the GCL of APP/PS1 mice, and the survival of more astrocytes in both WT and APP/PS1 mice after overexpression of sAPP $\alpha$. Finally, we also found a decrease in amyloid plaque levels after treatment. Our results may reveal one of the cellular mechanisms for memory rescue found with $\mathrm{SAPP} \alpha$ overexpression in previous studies $[17,18]$. These findings, together with the known importance of adult-hippocampal neurogenesis in memory formation and retention, support the possibility that SAPP $\alpha$ could be used therapeutically in AD to restore memory [53].

\section{Supplementary Information}

The online version contains supplementary material available at https://doi. org/10.1186/s13041-021-00889-1.

Additional file 1. Excel file holding the raw data for the results reported in this paper.

\section{Acknowledgements}

We thank Livia Kelly and Annalis Johnson for assistance with image analysis, Katie Peppercorn for assistance with genotyping, and Associate Professor Pete Jones and Health Research Council project grant 20/370 for support to complete the manuscript.

\section{Authors' contributions}

SMO, WCA, SMH and WPT designed the experiments; SMO and CC conducted the experiments; LS designed the plasmid; HW packaged the GFP AAV; SMO wrote the first draft; WCA, SMH, SMO, CC, HW, LS, WPT revised and edited the manuscript. All authors read and approved the final manuscript.

\section{Funding}

This project was funded by grant 1620-PG from the Neurological Foundation of New Zealand to WCA, SMH and WPT, and by grants from Brain Research New Zealand to SMH and WCA. The funding bodies played no role in the design, conduct, analysis, interpretation or manuscript writing of this submission.

\section{Availability of data and materials}

Data and materials will be made upon reasonable request to the corresponding author.

\section{Declarations}

Ethics approval and consent to participate

All animal use and procedures were approved by the University of Otago Animal Ethics Committee and conducted in accordance with New Zealand Animal Welfare legislation.

Consent for publication

Not applicable.

Competing interests

The authors declare that they have no competing financial or non-financial interests in the project. 


\section{Author details}

'Department of Psychology, Brain Health Research Centre, Brain Research New Zealand, University of Otago, Dunedin, New Zealand. '²epartment of Physiology, Brain Health Research Centre, Brain Research New Zealand, University of Otago, Dunedin, New Zealand. ${ }^{3}$ Department of Biochemistry, Brain Health Research Centre, Brain Research New Zealand, University of Otago, Dunedin, New Zealand.

Received: 30 September 2021 Accepted: 19 December 2021 Published online: 03 January 2022

\section{References}

1. Bloom GS. Amyloid- $\beta$ and tau: the trigger and bullet in Alzheimer disease pathogenesis. JAMA Neurol. 2014;71:505-8.

2. Selkoe DJ. The molecular pathology of Alzheimer's disease. Neuron. 1991:6:487-98.

3. Hillen $\mathrm{H}$. The beta amyloid dysfunction (BAD) hypothesis for Alzheimer's disease. Front Neurosci. 2019;13:1154

4. Turner BH, Mishkin M, Knapp M. Organization of the amygdalopetal projections from modality-specific cortical association areas in the monkey. J Comp Neurol. 1980;191:515-43.

5. Turner PR, O'Connor K, Tate WP, Abraham WC. Roles of amyloid precursor protein and its fragments in regulating neural activity, plasticity and memory. Prog Neurobiol. 2003;70:1-32.

6. Barger SW, Mattson MP. Induction of neuroprotective kappa B-dependent transcription by secreted forms of the Alzheimer's beta-amyloid precursor. Mol Brain Res. 1996;40:116-26.

7. Mucke L, Abraham CR, Masliah E. Neurotrophic and neuroprotective effects of hAPP in transgenic mice. Ann NY Acad Sci. 1996;777:82-8.

8. Mattson MP, Cheng B, Culwell AR, Esch FS, Lieberburg I, Rydel RE. Evidence for excitoprotective and intraneuronal calcium-regulating roles for secreted forms of the beta-amyloid precursor protein. Neuron. 1993;10:243-54

9. Thornton E, Vink R, Blumbergs PC, Van Den Heuvel C. Soluble amyloid precursor protein a reduces neuronal injury and improves functional outcome following diffuse traumatic brain injury in rats. Brain Res. 2006;1094:38-46.

10. Bour A, Little S, Dodart JC, Kelche C, Mathis C. A secreted form of the beta-amyloid precursor protein (SAPP695) improves spatial recognition memory in OF1 mice. Neurobiol Learn Mem. 2004:81:27-38.

11. Meziane H, Dodart J-C, Mathis C, Little S, Clemens J, Paul SM, et al. Memory-enhancing effects of secreted forms of the amyloid precursor protein in normal and amnestic mice. Proc Natl Acad Sci USA. 1998;95:12683-8.

12. Anderson JJ, Holtz G, Baskin PP, Wang R, Mazzarelli L, Wagner SL, et al. Reduced cerebrospinal fluid levels of a-secretase-cleaved amyloid precursor protein in aged rats: correlation with spatial memory deficits. Neuroscience. 1999;93:1409-20.

13. Almkvist $\mathrm{O}$, Basun $\mathrm{H}$, Wagner $\mathrm{SL}$, Rowe BA, Wahlund L-O, Lannfelt L. Cerebrospinal fluid levels of alpha-secretase-cleaved soluble amyloid precursor protein mirror cognition in a Swedish family with Alzheimer disease and a gene mutation. Arch Neurol. 1997:54:641-4.

14. Claasen AM, Guévremont D, Mason-Parker SE, Bourne K, Tate WP, Abraham WC, et al. Secreted amyloid precursor protein-a upregulates synaptic protein synthesis by a protein kinase G-dependent mechanism. Neurosci Lett. 2009:460:92-6.

15. Ryan MM, Morris G, Mockett B, Bourne K, Abraham WC, Tate WP, Williams JM. Secreted amyloid precursor protein-alpha mediates neuroprotection and induces hippocampal gene networks. BMC Genomics. 2013;14:376.

16. Taylor CJ, Ireland DR, Ballagh I, Bourne K, Marechal NM, Turner PR, et al. Endogenous secreted amyloid precursor protein-a regulates hippocampal NMDA receptor function, long-term potentiation and spatial memory. Neurobiol Dis. 2008:31:250-60.

17. Tan VTY, Mockett BG, Ohline SM, Parfitt KD, Wicky HE, Peppercorn K, et al. Lentivirus-mediated expression of human secreted amyloid precursor protein-alpha prevents development of memory and plasticity deficits in a mouse model of Alzheimer's disease. Mol Brain. 2018:11:7.

18. Fol R, Braudeau J, Ludewig S, Abel T, Weyer SW, Roederer JP, et al. Viral gene transfer of APPsalpha rescues synaptic failure in an Alzheimer's disease mouse model. Acta Neuropathol. 2016;131:247-66.
19. Altman J, Das GD. Autoradiographic and histological evidence of postnatal hippocampal neurogenesis in rats. J Comp Neurol. 1965;124:319-35.

20. Kempermann G, Kuhn HG, Gage FH. More hippocampal neurons in adult mice living in an enriched environment. Nature. 1997;386:493-5.

21. van Praag H, Christie BR, Sejnowski TJ, Gage FH. Running enhances neurogenesis, learning, and long-term potentiation in mice. Proc Natl Acad Sci USA. 1999;96:13427-31.

22. Kempermann G, Wiskott L, Gage FH. Functional significance of adult neurogenesis. Curr Opin Neurobiol. 2004;14:186-91.

23. Moreno-Jiménez EP, Flor-García M, Terreros-Roncal J, Rábano A, Cafini F, Pallas-Bazarra N, et al. Adult hippocampal neurogenesis is abundant in neurologically healthy subjects and drops sharply in patients with Alzheimer's disease. Nat Med. 2019;25:554-60.

24. Kesner RP. A behavioral analysis of dentate gyrus function. Prog Brain Res. 2007;163:567-76.

25. Gu Y, Arruda-Carvalho M, Wang J, Janoschka SR, Josselyn SA, Frankland PW, et al. Optical controlling reveals time-dependent roles for adult-born dentate granule cells. Nat Neurosci. 2012;15:1700-6.

26. Zhuo JM, Tseng HA, Desai M, Bucklin ME, Mohammed Al, Robinson NT, et al. Young adult born neurons enhance hippocampal dependent performance via influences on bilateral networks. Elife. 2016. https://doi. org/10.7554/eLife.22429.

27. Ge S, Yang $\mathrm{CH}, \mathrm{Hsu} \mathrm{KS}$, Ming GL, Song $\mathrm{H}$. A critical period for enhanced synaptic plasticity in newly generated neurons of the adult brain. Neuron. 2007:54:559-66.

28. Kee $\mathrm{N}$, Teixeira $\mathrm{CM}$, Wang $\mathrm{AH}$, Frankland PW. Preferential incorporation of adult-generated granule cells into spatial memory networks in the dentate gyrus. Nat Neurosci. 2007;10:355-62

29. Feng R, Rampon C, Tang YP, Shrom D, Jin J, Kyin M, et al. Deficient neurogenesis in forebrain-specific presenilin-1 knockout mice is associated with reduced clearance of hippocampal memory traces. Neuron. 2001;32:911-26.

30. Kempermann G, Gast D, Gage FH. Neuroplasticity in old age: sustained fivefold induction of hippocampal neurogenesis by long-term environmental enrichment. Ann Neurol. 2002:52:135-43.

31. Gould E, McEwen BS, Tanapat P, Galea LA, Fuchs E. Neurogenesis in the dentate gyrus of the adult tree shrew is regulated by psychosocial stress and NMDA receptor activation. J Neurosci. 1997:17:2492-8.

32. Hamilton A, Holscher C. The effect of ageing on neurogenesis and oxidative stress in the APP(swe)/PS1(deltaE9) mouse model of Alzheimer's disease. Brain Res. 2012;1449:83-93.

33. Liu H, Xue X, Shi H, Qi L, Gong D. Osthole upregulates BDNF to enhance adult hippocampal neurogenesis in APP/PS1 transgenic mice. Biol Pharm Bull. 2015;38:1439-49.

34. Zhu L, Yang JY, Xue X, Dong YX, Liu Y, Miao FR, et al. A novel phosphodiesterase-5 Inhibitor: Yonkenafil modulates neurogenesis, gliosis to improve cognitive function and ameliorates amyloid burden in an APP/PS1 transgenic mice model. Mech Ageing Dev. 2015;150:34-45.

35. Clelland CD, Choi M, Romberg C, Clemenson GD Jr, Fragniere A, Tyers $P$, et al. A functional role for adult hippocampal neurogenesis in spatial pattern separation. Science. 2009:325:210-3.

36. Trouche S, Bontempi B, Roullet P, Rampon C. Recruitment of adultgenerated neurons into functional hippocampal networks contributes to updating and strengthening of spatial memory. Proc Natl Acad Sci USA. 2009;106:5919-24.

37. Ohline SM, Wake KL, Hawkridge MV, Dinnunhan MF, Hegemann RU, Wilson A, et al. Adult-born dentate granule cell excitability depends on the interaction of neuron age, ontogenetic age and experience. Brain Struct Funct. 2018;223:3213-28.

38. Krezymon A, Richetin K, Halley H, Roybon L, Lassalle JM, Frances B, et al. Modifications of hippocampal circuits and early disruption of adult neurogenesis in the $\operatorname{tg} 2576$ mouse model of Alzheimer's disease. PLoS ONE. 2013;8: e76497.

39. Verret L, Jankowsky JL, Xu GM, Borchelt DR, Rampon C. Alzheimer'stype amyloidosis in transgenic mice impairs survival of newborn neurons derived from adult hippocampal neurogenesis. J Neurosci. 2007;27:6771-80

40. Li D, Tang J, Xu H, Fan X, Bai Y, Yang L. Decreased hippocampal cell proliferation correlates with increased expression of BMP4 in the APPswe/PS1DeltaE9 mouse model of Alzheimer's disease. Hippocampus. 2008:18:692-8 
41. Donovan MH, Yazdani U, Norris RD, Games D, German DC, Eisch AJ. Decreased adult hippocampal neurogenesis in the PDAPP mouse model of Alzheimer's disease. J Comp Neurol. 2006;495:70-83.

42. Ermini FV, Grathwohl S, Radde R, Yamaguchi M, Staufenbiel M, Palmer TD, et al. Neurogenesis and alterations of neural stem cells in mouse models of cerebral amyloidosis. Am J Pathol. 2008;172:1520-8.

43. Jin K, Peel AL, Mao XO, Xie L, Cottrell BA, Henshall DC, et al. Increased hippocampal neurogenesis in Alzheimer's disease. Proc Natl Acad Sci USA. 2004:101:343-7.

44. Demars M, Hu YS, Gadadhar A, Lazarov O. Impaired neurogenesis is an early event in the etiology of familial Alzheimer's disease in transgenic mice. J Neurosci Res. 2010;88:2103-17.

45. Hu YS, Xu P, Pigino G, Brady ST, Larson J, Lazarov O. Complex environment experience rescues impaired neurogenesis, enhances synaptic plasticity, and attenuates neuropathology in familial Alzheimer's disease-linked APPswe/PS1DeltaE9 mice. FASEB J. 2010;24:1667-81.

46. Parthsarathy V, Hölscher C. Chronic treatment with the GLP1 analogue liraglutide increases cell proliferation and differentiation into neurons in an AD mouse model. PLoS ONE. 2013;8: e58784.

47. Zhang C, McNeil E, Dressler L, Siman R. Long-lasting impairment in hippocampal neurogenesis associated with amyloid deposition in a knock-in mouse model of familial Alzheimer's disease. Exp Neurol. 2007;204:77-87.

48. Caille I, Allinquant B, Dupont E, Bouillot C, Langer A, Müller U, et al. Soluble form of amyloid precursor protein regulates proliferation of progenitors in the adult subventricular zone. Development. 2004;131:2173-81.

49. Demars MP, Bartholomew A, Strakova Z, Lazarov O. Soluble amyloid precursor protein: a novel proliferation factor of adult progenitor cells of ectodermal and mesodermal origin. Stem Cell Res Therapy. 2011;2:36.

50. Demars MP, Hollands C, Zhao Kda T, Lazarov O. Soluble amyloid precursor protein-alpha rescues age-linked decline in neural progenitor cell proliferation. Neurobiol Aging. 2013;34:2431-40

51. Scopa C, Marrocco F, Latina V, Ruggeri F, Corvaglia V, La Regina F, et al. Impaired adult neurogenesis is an early event in Alzheimer's disease neurodegeneration, mediated by intracellular $A \beta$ oligomers. Cell Death Differ. 2020:27:934-48.

52. Baratchi S, Evans J, Tate WP, Abraham WC, Connor B. Secreted amyloid precursor proteins promote proliferation and glial differentiation of adult hippocampal neural progenitor cells. Hippocampus. 2012;22:1517-27.

53. Mockett BG, Richter M, Abraham WC, Müller UC. Therapeutic potential of secreted amyloid precursor protein APPsa. Front Mol Neurosci. 2017; 10:30.

54. Claasen AM, Guévremont D, Mason-Parker SE, Bourne K, Tate WP, Abraham WC, et al. Secreted amyloid precursor protein-a upregulates synaptic protein synthesis by a protein kinase $\mathrm{G}$-dependent mechanism. Neurosci Lett. 2009;460:92-6.

55. Hoeijmakers L, Amelianchik A, Verhaag F, Kotah J, Lucassen PJ, Korosi A. Early-life stress does not aggravate spatial memory or the process of hippocampal neurogenesis in adult and middle-aged APP/PS1 mice. Front Aging Neurosci. 2018. https://doi.org/10.3389/fnagi.2018.00061.

56. Wen PH, Hof PR, Chen X, Gluck K, Austin G, Younkin SG, et al. The presenilin-1 familial Alzheimer disease mutant P117L impairs neurogenesis in the hippocampus of adult mice. Exp Neurol. 2004;188:224-37.

57. Freude KK, Penjwini M, Davis JL, LaFerla FM, Blurton-Jones M. Soluble amyloid precursor protein induces rapid neural differentiation of human embryonic stem cells. J Biol Chem. 2011;286:24264-74.

58. Porayette P, Gallego MJ, Kaltcheva MM, Bowen RL, Vadakkadath Meethal S, Atwood CS. Differential processing of amyloid-beta precursor protein directs human embryonic stem cell proliferation and differentiation into neuronal precursor cells. J Biol Chem. 2009;284:23806-17.

59. Kol A, Adamsky A, Groysman M, Kreisel T, London M, Goshen I. Astrocytes contribute to remote memory formation by modulating hippocampalcortical communication during learning. Nat Neurosci. 2020;23:1229-39.

60. Clark PJ, Brzezinska WJ, Thomas MW, Ryzhenko NA, Toshkov SA, Rhodes JS. Intact neurogenesis is required for benefits of exercise on spatial memory but not motor performance or contextual fear conditioning in C57BL/6J mice. Neuroscience. 2008;155:1048-58.

61. Kobilo T, Liu QR, Gandhi K, Mughal M, Shaham Y, van Praag H. Running is the neurogenic and neurotrophic stimulus in environmental enrichment. Learn Mem. 2011;18:605-9.
62. Fabel K, Wolf SA, Ehninger D, Babu H, Leal-Galicia P, Kempermann G. Additive effects of physical exercise and environmental enrichment on adult hippocampal neurogenesis in mice. Front Neurosci. 2009;3:50.

63. van Praag H, Kempermann G, Gage FH. Running increases cell proliferation and neurogenesis in the adult mouse dentate gyrus. Nat Neurosci. 1999;2:266-70.

64. Cameron HA, Woolley CS, McEwen BS, Gould E. Differentiation of newly born neurons and glia in the dentate gyrus of the adult rat. Neuroscience. 1993;56:337-44.

65. Czéh B, Welt T, Fischer AK, Erhardt A, Schmitt W, Müller MB, et al. Chronic psychosocial stress and concomitant repetitive transcranial magnetic stimulation: effects on stress hormone levels and adult hippocampal neurogenesis. Biol Psychiatry. 2002;52:1057-65.

66. Duque A, Spector R. A balanced evaluation of the evidence for adult neurogenesis in humans: implication for neuropsychiatric disorders. Brain Struct Funct. 2019;224:2281-95.

67. Kempermann G. Why new neurons? Possible functions for adult hippocampal neurogenesis. J Neurosci. 2002;22(3):635-8.

68. Prickaerts J, Koopmans G, Blokland A, Scheepens A. Learning and adult neurogenesis: survival with or without proliferation? Neurobiol Learn Mem. 2004;81(1):1-11.

69. Nigam SM, Xu S, Kritikou JS, Marosi K, Brodin L, Mattson MP. Exercise and $B D N F$ reduce $A \beta$ production by enhancing a-secretase processing of APP. J Neurochem. 2017;142:286-96.

70. Obregon D, Hou H, Deng J, Giunta B, Tian J, Darlington D, et al. Soluble amyloid precursor protein-a modulates $\beta$-secretase activity and amyloid- $\beta$ generation. Nat Commun. 2012;3:777.

71. Casanova F, Carney PR, Sarntinoranont M. Effect of needle insertion speed on tissue injury, stress, and backflow distribution for convectionenhanced delivery in the rat brain. PLoS ONE. 2014;9: e94919.

\section{Publisher's Note}

Springer Nature remains neutral with regard to jurisdictional claims in published maps and institutional affiliations.

\footnotetext{
Ready to submit your research? Choose BMC and benefit from:

- fast, convenient online submission

- thorough peer review by experienced researchers in your field

- rapid publication on acceptance

- support for research data, including large and complex data types

- gold Open Access which fosters wider collaboration and increased citations

- maximum visibility for your research: over $100 \mathrm{M}$ website views per year
}

At BMC, research is always in progress.

Learn more biomedcentral.com/submissions 